EISSN:2706-7920 ISSN: 2077-4435

DOI: $10.36632 / \mathrm{csi} / 2021.10 .4 .51$

Journal homepage: www.curresweb.com

Pages: 599-622

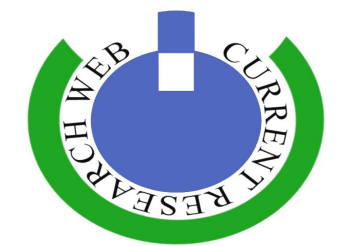

\title{
Ionic Ratios as Tracers to Assess Seawater Intrusion and To Identify Salinity Sources in Ras Sudr Coastal Aquifer, South West Sinai, Egypt
}

\author{
Reda G.M. Ibrahim ${ }^{1}$, Mohamed E.A. Ali' ${ }^{1}$, Yasmeen M. Abdel Satar ${ }^{1}$, Magdy Sabaa ${ }^{2}$ \\ and Hend Ezzat ${ }^{2}$
}

${ }^{1}$ Hydrogeochemistry Dept., Desert Research Center, Cairo, Egypt.

${ }^{2}$ Chemistry Dept., Cairo University, El Giza, Egypt.

Received: 12 Oct. $2021 \quad$ Accepted: 11 Nov. $2021 \quad$ Published: 15 Nov. 2021

\begin{abstract}
Ras Sudr area located at the eastern side of the Gulf of Suez, southwest of Sinai Peninsula, Egypt where groundwater is exploited mainly from the Quaternary aquifer. The matrix of this aquifer is composed of alluvium deposits made up of gravel intercalated with clay and calcareous sandstone. The groundwater of the Quaternary aquifer is mainly brackish to saline (TDS=2038 to $24383 \mathrm{mg} / \mathrm{l}$ ) and this aquifer is recharged mainly from rainfall and surface runoff due to the occasional flash floods. The main purpose of this study is to investigate the main hydrogeochemical factors (especially the seawater intrusion) which affect the groundwater quality by the integration between the hydrogeochemical tools and multivariate statistical analysis. The current study proves that ionic ratios are important tools in the assessment of the seawater intrusion process. The cluster analysis shows that the wells included in cluster (CI) and cluster (CII) which located north of the mapped area are strongly affected by seawater intrusion. Wells of cluster (CIII) at the middle part of the study area (Wadi Sudr and its northern extension) are moderately affected by seawater intrusion, while wells of this cluster at the southern part (i.e., Wadi Wardan) are less affected by this process. The results of seawater fractions match well with the cluster analysis since the seawater fraction percents are high, medium and low at the northern, middle and southern parts of the study area, respectively. The other processes affecting groundwater quality of the Quaternary aquifer include ion exchange and waterrock interactions. The integration between the conventional geochemical and multivariate statistical tools in this study can applied for similar coastal aquifers worldwide.
\end{abstract}

Keywords: The Quaternary aquifer. Seawater intrusion. Ion exchange. Cluster analysis. Sudr area. Egypt

\section{Introduction}

Ras Sudr area is situated on the eastern side of the Gulf of Suez in the southwestern part of Sinai Peninsula. It has a surface area of $280 \mathrm{~km}^{2}$ and it is bounded between latitudes $29^{\circ} 30^{\prime}$ and $29^{\circ}$ $45^{\prime} \mathrm{N}$ and longitudes $32^{\circ} 40^{\prime}$ and $32^{\circ} 47^{\prime} \mathrm{E}$ (Fig. 1). In the study area, the groundwater is drawn from the Quaternary shallow aquifer which represents the main source of water that used for irrigation and domestic purposes. The study area is considered a promising and strategic place for urban, touristic and agriculture expansion activities due to its closeness to the regions of Suez Canal, Cairo, and Nile Delta. The area under study as a part of South Sinai region is characterized by arid climate with high temperature (the maximum average monthly temperature is $35{ }^{\circ} \mathrm{C}$ and evaporation rate reaches 15.7 $\mathrm{mm}$ in June. The rainfall is scarce and limited with irregular occurrence of flash floods during autumn and winter seasons.

Many studies were carried out on Ras Sudr area. Abdel Hafez (2001) studied the hydrochemistry of the delta of Wadi Sudr area. Abdel-Lattif and Sherief (2010) used the results of the morphometric parameters and the new data of the flash flood which occurred on 17-18 $8^{\text {th }}$ January 2010 to study the risk of flash floods on Wadi Sudr basin. In case of lack management, the floods cause 
more damages of Bedouin villages, the infrastructure in urban centers, water and oil pipes, bridges, roads, and touristic sites. Wadi Sudr is considered as one of the most active wadis in Sinai; former floods at this area have destroyed and devastated long parts of roads (especially Suez-Sharm El Sheikh Road) and damaged urban centers, water and oil pipes, bridges, and touristic sites as well. ElFiky (2010) investigated the hydrogeochemical and isotopic data of groundwaters of the different aquifers of the Ras Sudr-Abu Zenima area to determine the main factors controlling the groundwater chemistry and salinity. Ibrahim (2012) used the hydrological data to explain the deterioration of the groundwater quality at Ras Sudr area by the encroachment of the seawater into the Quaternary aquifer due to the lowering of the freshwater table in relation to excessive groundwater withdrawal. Hussien (2015) used the Geographic Information System (GIS), statistical techniques combined with groundwater quality index specific for seawater intrusion (GQISWI) to characterize vulnerability to seawater intrusion and to understand factors controlling the groundwater chemistry in Ras Sudr area and its vicinities. Abo Shalaa (2016) conducted isotope study using the analyses for ${ }^{18} \mathrm{O}$ and ${ }^{2} \mathrm{H}$ which displayed an isotopic signature close to that of meteoric water with d-excess values $(5.7-20.08 \%$ o) indicating present-day precipitation over the region. Moreover, this isotopic investigation indicated the effect of evaporation on the shallow water horizon of the Quaternary aquifer.

The investigation of the hydrogeochemical processes affecting groundwater systems help to know about the contribution of geogenic and anthropogenic influences on the groundwater composition. The modification of groundwater chemical composition is the reflection of the water constituents that react with minerals present at the aquifer matrices through which the groundwater flow. The present study aims to evaluate mainly the seawater intrusion and other hydrogeochemical processes such as ion exchange, leaching and dissolution processes which control the chemistry of the Quaternary groundwater at Sudr area and its vicinities (i.e., the Wadis of Lahata and Wardan) under arid and semi-arid conditions. The good understanding of such hydrogeochemical processes contribute to the real management strategy and enable for effective utilization of the groundwater for various human activities.

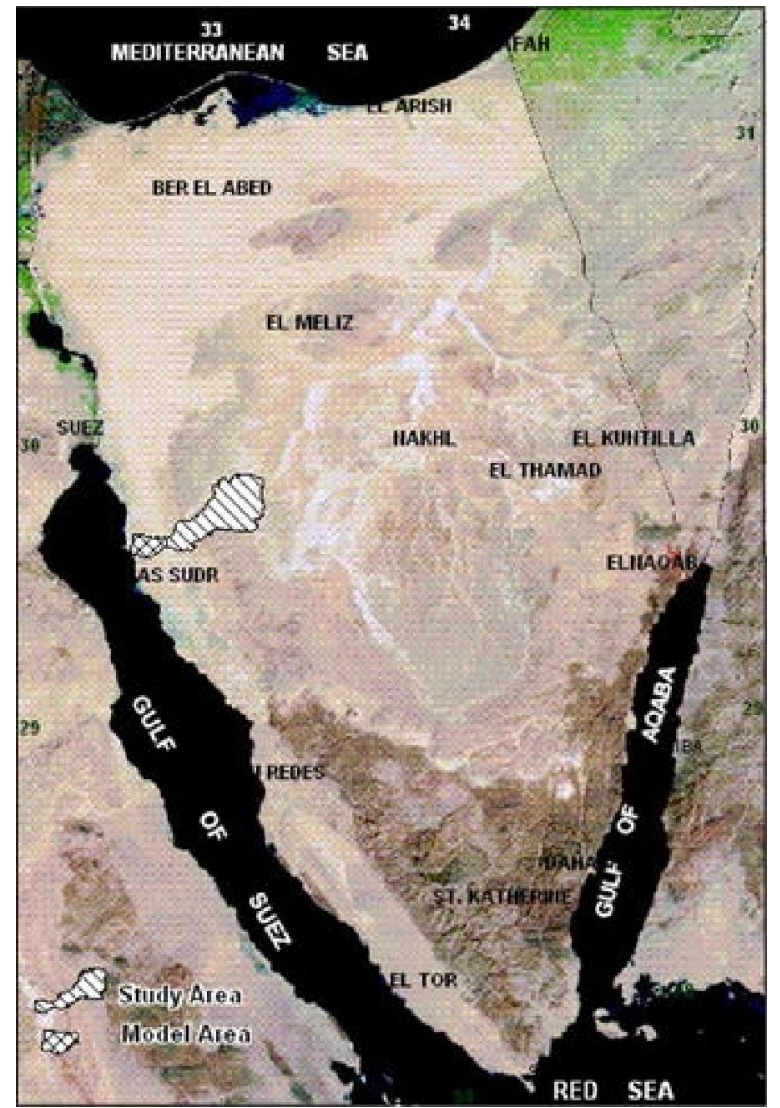

Fig. 1: Key map of Ras Sudr area and its vicinities, southwest Sinai, Egypt. 


\section{Physical setting}

\subsection{Geomorphological and geological aspects}

From a geomorphologic point of view, Wadi Sudr and its vicinities comprise four geomorphologic units; (1) the dissected table land, (2) the hilly area, (3) the tectonic depressions and (4) the Gulf of Suez coastal plain. This plain is covered by gravels, sands and clay forming remnants of old terraces. Based on the Digital Elevation Model (Fig. 2) derived from SRTM data acquired by the National Aeronautics and Space Administration (NASA) in February 2000, the regional slope is from the eastern side (where the tableland and hilly areas exist and the elevation reaches $+100 \mathrm{~m}$ ) towards the western side, i.e. towards the Gulf of Suez where the elevation is less than $+10 \mathrm{~m}$. The study area belong the coastal plain (the fourth unit).
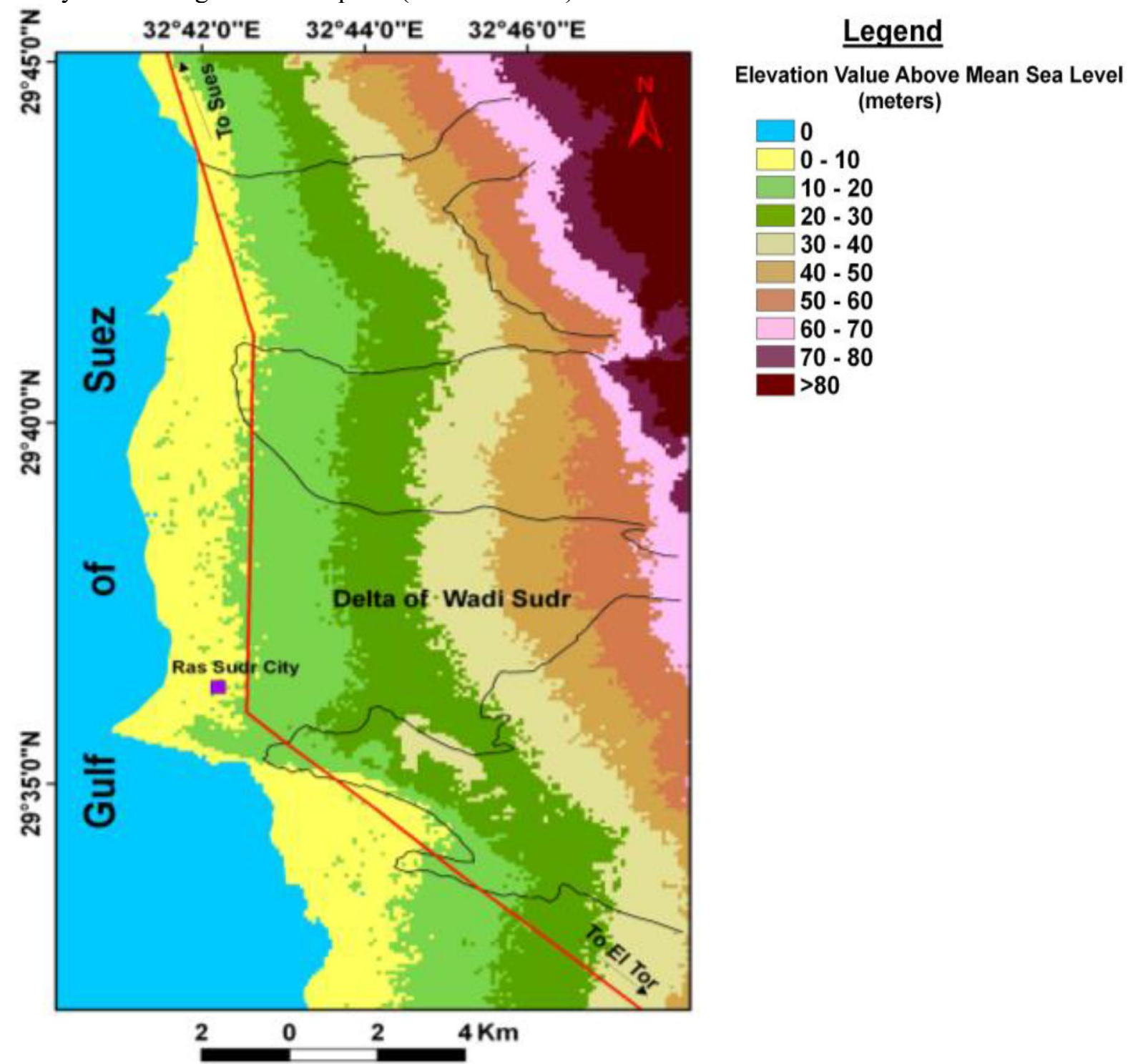

Fig. 2: Digital Elevation Model (DEM) of Wadi Sudr and its vicinities created from SRTM data which acquired by NASA at the year 2000 (Ibrahim, 2012).

The geology of the southwestern part of Sinai extended along the Gulf of Suez comprises sedimentary succession ranges in age between Upper Cretaceous carbonate rocks, Lower Miocene sandstone and evaporites to Quaternary clastic alluvial deposits (Fig. 3, Hammad 1980; Conoco 1987; Hasanein 1989; Gad 1996; El-Fiky, 2010; Abo Shalaa, 2016). Furthermore, the geophysical study of Abdel Latif and Al Temamy (2008) for the drilled wells in the Delta of Wadi Sudr revealed that the subsurface lithologic sequence is restricted to the Miocene Limestone and the Quaternary alluvium deposits. The thickness of the Quaternary alluvial deposits, which cover the study area, varies widely 
from the upstream to downstream where it is encountered at the upstream of the wadis dissecting Gebel Sin Bisher, Gebel El Raha and Gebel Somar with a thickness of less than $5 \mathrm{~m}$. In turn, this thickness reaches about $50 \mathrm{~m}$ at the delta or outlet of the wadis, this means it increases towards the Gulf of Suez. Structurally, Sudr area is subjected to some tectonic movements which lead to development of some structural elements such as fractures and faults (Abdel Gawad 1970; Said 1990).
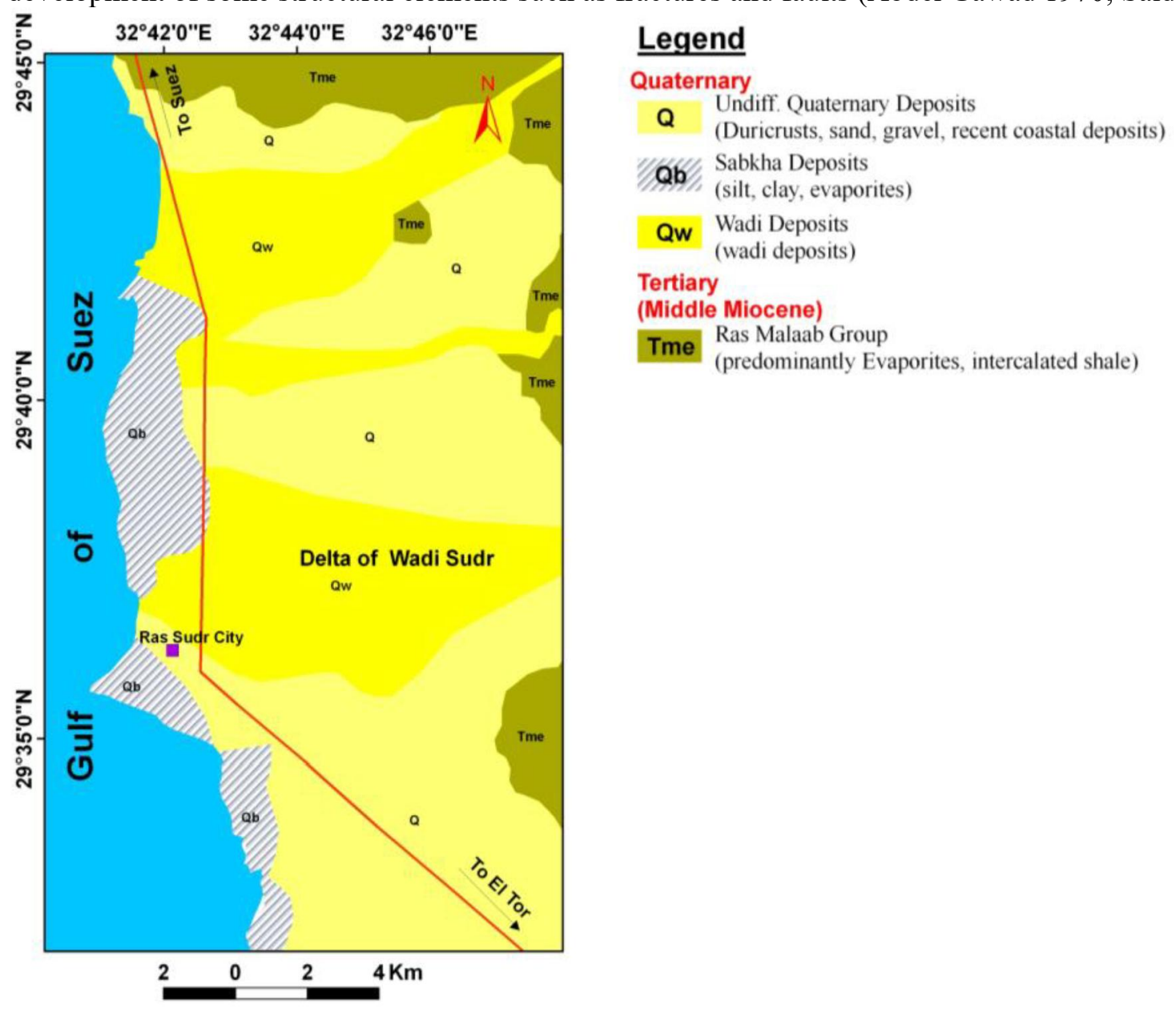

Fig. 3: Geologic map of Ras Sudr area and its vicinities, Egypt (Conoco, 1987).

\subsection{Hydrogeological conditions}

Groundwater of Wadi Sudr area and its vicinity is available from three main aquifers belonging to Upper Cretaceous (fractured limestone), Miocene (sandstone and evaporites) and Quaternary (Wadi fill and alluvial deposits) aquifers (Abo Shalaa 2016). The current study focuses on the Quaternary aquifer through the inventory of 39 wells (Fig. 4) tapping this aquifer. Such investigations include data collection, field measurements of the depth to water (DTW) and total depths (TD). The depth to the Quaternary groundwater ranges from 3 to $38 \mathrm{~m}$ during 2010 (Ibrahim 2012) while it ranges between 4.5 and $24.2 \mathrm{~m}$ during 2018 (Maher 2020). This means that there is a decline in water levels with time. The total drilling depth of the investigated wells ranges between $6 \mathrm{~m}$ and $60 \mathrm{~m}$. The Quaternary aquifer is the main aquifer in Wadi Sudr and its vicinities, where the Quaternary sediments are composed of alluvium deposits made up of gravel intercalated with varicolored clay and calcareous sandstone (Hassanein 1989; Misak et al., 1995; El Sayed et al., 1999). The general groundwater flow direction is from east towards west, i.e., towards the Gulf of Suez which is considered the natural discharge area for the groundwater encountered at the Quaternary aquifer. The recharge of this aquifer is from rainfall (mainly from the occasional flash floods and also from surface runoff coming from the upstream at the eastern areas). A third possible recharge source is the upward leakage from the deeper aquifers (El-Fiky, 2010; Abo Shalaa 2016), while the discharged groundwater is used mainly for irrigation. 


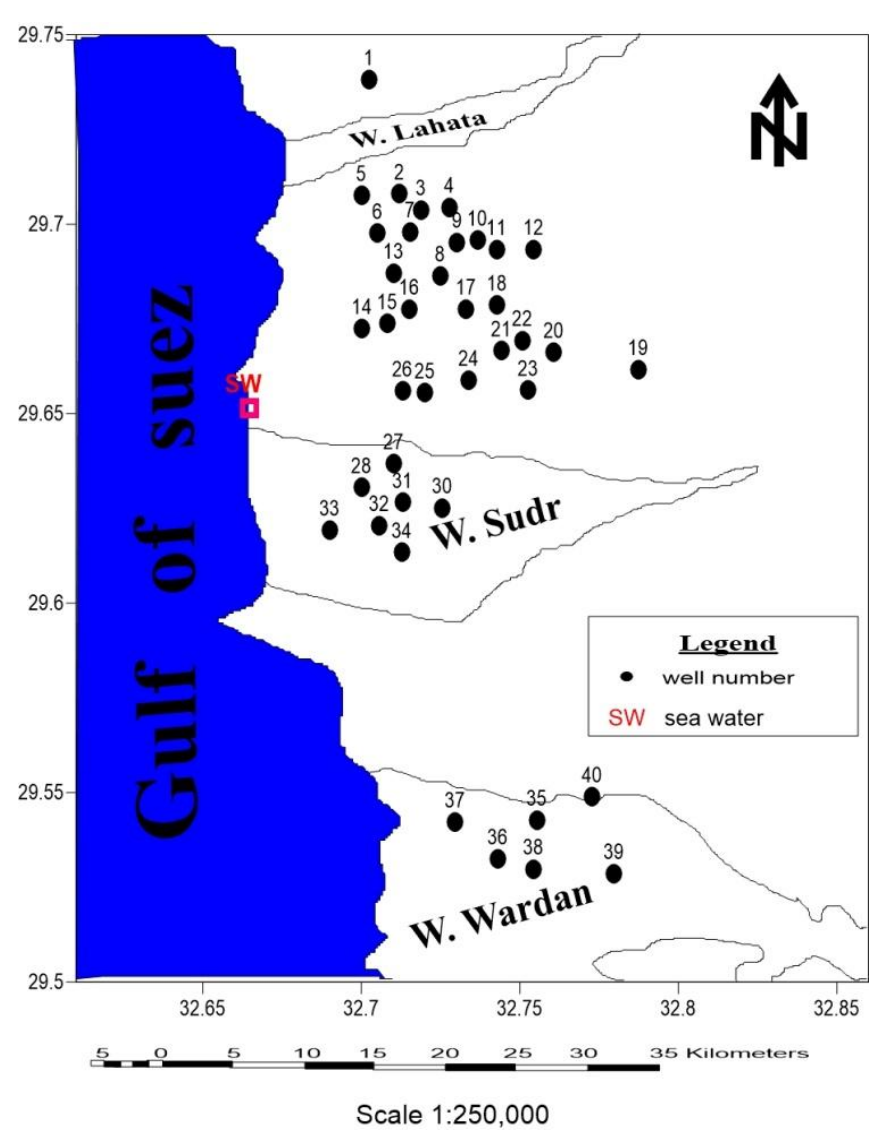

Fig. 4: Wells' location map of Ras Sudr area and its vicinities, southwest Sinai, Egypt.

\section{Collection of samples and methodology}

A set of 40 water samples (including 39 groundwater samples and 1 sample from the Gulf of Suez) were collected from Ras Sudr area, South Sinai (see Fig. 4) during two field trips in the years 2017 and 2018. Most of the groundwater wells are drilled with rotary machine and some of them are hand dug. Immediately after sampling, temperature, $\mathrm{pH}$ and electrical conductivity (EC) were measured in the field using some portable meters. Subsequently, the samples were analyzed for their major chemical constituents, i.e., calcium, magnesium, sodium, potassium, chloride, bicarbonate, and sulfate. This was achieved using standard methods as suggested by the American Public Health Association (APHA, 1995) and the American Society for Testing Materials (ASTM 2002). $\mathrm{Ca}^{2+}$, $\mathrm{Mg}^{2+}, \mathrm{Na}^{+}, \mathrm{K}^{+}, \mathrm{SO}_{4}{ }^{2-}, \mathrm{Cl}^{-}$concentrations were estimated using a Thermo Scientific Ion Chromatograph (IC), model Dionex, ICS-1100. The concentrations of $\left(\mathrm{HCO}_{3}{ }^{-} \& \mathrm{CO}_{3}{ }^{2-}\right)$ and $\mathrm{Cl}^{-}$were estimated by titration against $\mathrm{H}_{2} \mathrm{SO}_{4}$ and $\mathrm{AgNO}_{3}$, respectively. The chemical analysis accuracy was achieved by calculating the ionic charge balance where the errors were generally within $\pm 5 \%$. The results of these chemical analyses are expressed in milligram per liter (mg/l) and they are listed in Table (1).

\section{Results and Discussion}

The chemistry of the groundwater samples collected from the area under investigation includes discussion of hydrogen ion concentration $(\mathrm{pH})$, water salinity (TDS), water chemical type, hydrochemical coefficients (Ionic ratio), leaching and dissolution processes, saturation indices, ion exchange, seawater fraction and seawater mixing index.

\subsection{Hydrogeochemical characteristics}

4.1.1 Hydrogen ion concentration $(\mathbf{p H})$ : The water samples exhibit $\mathrm{pH}$ values ranging from 6.8 to 8 , which indicate that the water is neutral to slightly alkaline. 
Table 1: The hydrochemical data of the groundwater samples collected from the Quaternary aquifer, Ras Sudr area, Egypt.

\begin{tabular}{|c|c|c|c|c|c|c|c|c|c|c|c|c|}
\hline Sample no. & $\mathbf{p H}$ & $\begin{array}{l}\text { TDS } \\
\mathrm{mg} / \mathrm{l}\end{array}$ & $\begin{array}{l}\mathrm{Ca}^{2+} \\
\mathrm{mg} / \mathrm{l}\end{array}$ & $\begin{array}{l}\mathrm{Mg}^{2+} \\
\mathrm{mg} / \mathrm{l}\end{array}$ & $\begin{array}{l}\mathrm{Na}^{+} \\
\mathrm{mg} / \mathrm{l}\end{array}$ & $\begin{array}{l}\mathrm{K}^{+} \\
\mathrm{mg} / \mathbf{l}\end{array}$ & $\begin{array}{l}\text { Total } \\
\text { cations } \\
\text { epm }\end{array}$ & $\begin{array}{l}\mathrm{CO}_{3}{ }^{2-} \\
\mathrm{mg} / \mathrm{l}\end{array}$ & $\begin{array}{l}\mathrm{HCO}_{3}^{-} \\
\mathrm{mg} / \mathrm{l}\end{array}$ & $\begin{array}{l}\mathrm{SO}_{4}{ }^{2-} \\
\mathrm{mg} / \mathrm{l}\end{array}$ & $\begin{array}{l}\mathrm{Cl}^{-} \\
\mathrm{mg} / \mathrm{l}\end{array}$ & $\begin{array}{l}\text { Total } \\
\text { anions } \\
\text { epm }\end{array}$ \\
\hline 1 & 7.3 & 24383 & 1715 & 695 & 6800 & 67 & 440.1 & 25 & 146 & 910 & 14097 & 419.7 \\
\hline 2 & 7.3 & 9638 & 750 & 354 & 2400 & 39 & 171.9 & 0 & 134 & 1100 & 4929 & 164.1 \\
\hline 3 & 7.6 & 12455 & 1450 & 520 & 2500 & 32 & 224.6 & 0 & 107 & 1400 & 6500 & 214.2 \\
\hline 4 & 7.1 & 14519 & 473 & 740 & 3700 & 50 & 246.6 & 19 & 174 & 1800 & 7650 & 256.7 \\
\hline 5 & 7.2 & 11470 & 710 & 450 & 2800 & 32 & 195.0 & 0 & 129 & 1400 & 6013 & 200.8 \\
\hline 6 & 7 & 7645 & 560 & 240 & 1800 & 19 & 126.4 & 0 & 150 & 1600 & 3352 & 130.3 \\
\hline 7 & 7.1 & 5925 & 427 & 250 & 1300 & 17 & 98.8 & 0 & 134 & 1400 & 2465 & 100.8 \\
\hline 8 & 7.2 & 9130 & 920 & 420 & 1800 & 20 & 159.2 & 0 & 140 & 2100 & 3800 & 153.1 \\
\hline 9 & 7.2 & 7918 & 510 & 240 & 1920 & 19 & 129.2 & 0 & 157 & 1700 & 3450 & 135.2 \\
\hline 10 & 7.5 & 4415 & 283 & 150 & 1010 & 14 & 70.7 & 0 & 159 & 1400 & 1479 & 73.4 \\
\hline 11 & 6.8 & 5566 & 441 & 176 & 1300 & 16 & 93.4 & 0 & 138 & 1100 & 2465 & 94.6 \\
\hline 12 & 7.4 & 3645 & 360 & 165 & 640 & 15 & 59.7 & 0 & 166 & 1200 & 1183 & 61.0 \\
\hline 13 & 7.4 & 5616 & 260 & 140 & 1500 & 19 & 90.2 & 18 & 120 & 1500 & 2120 & 93.5 \\
\hline 14 & 7.5 & 5043 & 287 & 144 & 1340 & 20 & 84.9 & 19 & 144 & 500 & 2662 & 88.5 \\
\hline 15 & 7.4 & 6592 & 480 & 180 & 1600 & 21 & 108.9 & 0 & 113 & 1100 & 3155 & 113.7 \\
\hline 16 & 7.8 & 12252 & 410 & 320 & 3600 & 30 & 204.1 & 11 & 131 & 2000 & 5816 & 208.1 \\
\hline 17 & 7.5 & 7197 & 420 & 220 & 1800 & 68 & 119.0 & 30 & 159 & 1100 & 3480 & 124.6 \\
\hline 18 & 7.7 & 7651 & 350 & 200 & 2100 & 15 & 125.6 & 12 & 138 & 1553 & 3352 & 129.5 \\
\hline 19 & 8 & 2202 & 147 & 61 & 540 & 10 & 36.0 & 30 & 96 & 480 & 887 & 37.6 \\
\hline 20 & 7.6 & 4618 & 210 & 120 & 1300 & 11 & 77.2 & 41 & 123 & 1100 & 1774 & 76.3 \\
\hline 21 & 7.1 & 2408 & 190 & 102 & 520 & 10 & 40.7 & 24 & 159 & 498 & 986 & 41.5 \\
\hline 22 & 6.9 & 8607 & 560 & 280 & 2100 & 16 & 142.7 & 35 & 111 & 1400 & 4160 & 149.4 \\
\hline 23 & 7.5 & 4216 & 230 & 170 & 1050 & 12 & 71.4 & 0 & 192 & 490 & 2169 & 74.5 \\
\hline 24 & 7.4 & 5283 & 260 & 160 & 1400 & 14 & 87.4 & 0 & 171 & 900 & 2465 & 91.0 \\
\hline 25 & 7.5 & 4670 & 230 & 198 & 1140 & 14 & 77.7 & 0 & 159 & 840 & 2169 & 81.2 \\
\hline 26 & 7.6 & 4603 & 290 & 180 & 1050 & 15 & 75.3 & 0 & 188 & 1200 & 1774 & 78.1 \\
\hline 27 & 7.4 & 5235 & 410 & 210 & 1100 & 16 & 86.0 & 0 & 253 & 1500 & 1873 & 88.2 \\
\hline 28 & 7.3 & 7613 & 480 & 310 & 1700 & 80 & 125.4 & 0 & 183 & 1600 & 3352 & 130.8 \\
\hline 30 & 7.2 & 6259 & 580 & 328 & 1150 & 13 & 106.3 & 0 & 201 & 1059 & 3028 & 110.7 \\
\hline 31 & 7.4 & 7393 & 660 & 352 & 1450 & 15 & 125.3 & 0 & 183 & 1001 & 3823 & 131.6 \\
\hline 32 & 7.5 & 6583 & 580 & 316 & 1300 & 13 & 111.8 & 0 & 171 & 913 & 3376 & 117.0 \\
\hline 33 & 7.4 & 7365 & 560 & 389 & 1500 & 17 & 125.6 & 0 & 159 & 947 & 3872 & 131.5 \\
\hline 34 & 7.4 & 2497 & 256 & 92 & 440 & 9 & 39.7 & 0 & 214 & 935 & 658 & 41.5 \\
\hline 35 & 7.5 & 2585 & 328 & 131 & 360 & 11 & 43.1 & 0 & 153 & 636 & 1043 & 45.1 \\
\hline 36 & 7.4 & 2038 & 248 & 97 & 280 & 9 & 32.8 & 0 & 171 & 760 & 559 & 34.4 \\
\hline 37 & 7.5 & 3166 & 424 & 151 & 360 & 15 & 49.6 & 0 & 146 & 1461 & 683 & 52.0 \\
\hline 38 & 7.5 & 2354 & 272 & 102 & 360 & 11 & 37.9 & 0 & 146 & 915 & 621 & 38.9 \\
\hline 39 & 7.5 & 2544 & 288 & 122 & 400 & 10 & 42.0 & 0 & 134 & 851 & 807 & 42.7 \\
\hline 40 & 7.6 & 6085 & 700 & 328 & 850 & 15 & 99.2 & 0 & 140 & 1962 & 2160 & 104.0 \\
\hline $29 *$ Seawater & 8 & 41163 & 610 & 1720 & 11800 & 450 & 696.4 & 36 & 146 & 3800 & 22674 & 722.0 \\
\hline
\end{tabular}

\subsubsection{Total dissolved solids (salinity of water)}

According to Chebotarev's classification (1955), the natural water can be classified into three main categories, as follow:

- Fresh water category; where TDS value is less than $1500 \mathrm{mg} / \mathrm{l}$.

- Brackish water category; where TDS value ranges between 1500 and $5000 \mathrm{mg} / \mathrm{l}$.

- Saline to extremely saline water category; where TDS value is more than $5000 \mathrm{mg} / \mathrm{l}$.

The term 'salinity' refers to the total dissolved solids including the major ions as well as minor and trace constituents. The concentration of solutes can vary extremely as a function of the mineral content of aquifers through which the groundwater flows. According to the obtained TDS values represented at Fig. 5, water salinity of the Quaternary groundwater ranges from $2038 \mathrm{mg} / 1$ (sample No. 36) to $24383 \mathrm{mg} / 1$ (sample No. 1) with mean value of $6679 \mathrm{mg} / \mathrm{l}$. The high salinity values of groundwater of the Quaternary aquifer is a result of the intensive well drilling operations and hence the excessive withdrawal relative to the current recharge. Furthermore, leaching and dissolution of gypsum and evaporites deposits, and evaporation from the shallow groundwater are considered as additional factors causing an increase in the water salinity (Morad 2000). Another possible cause of 
salinity may be due to mixing with underlying dense salt water because of the over-pumping (El-Fiky, 2010). Comparing the chemical analyses of water samples (see table 1), with Chebotarev's classification, it was clear that the majority of water samples $(64 \%)$ are related to saline - extremely saline category and $36 \%$ of samples belong to brackish water category.

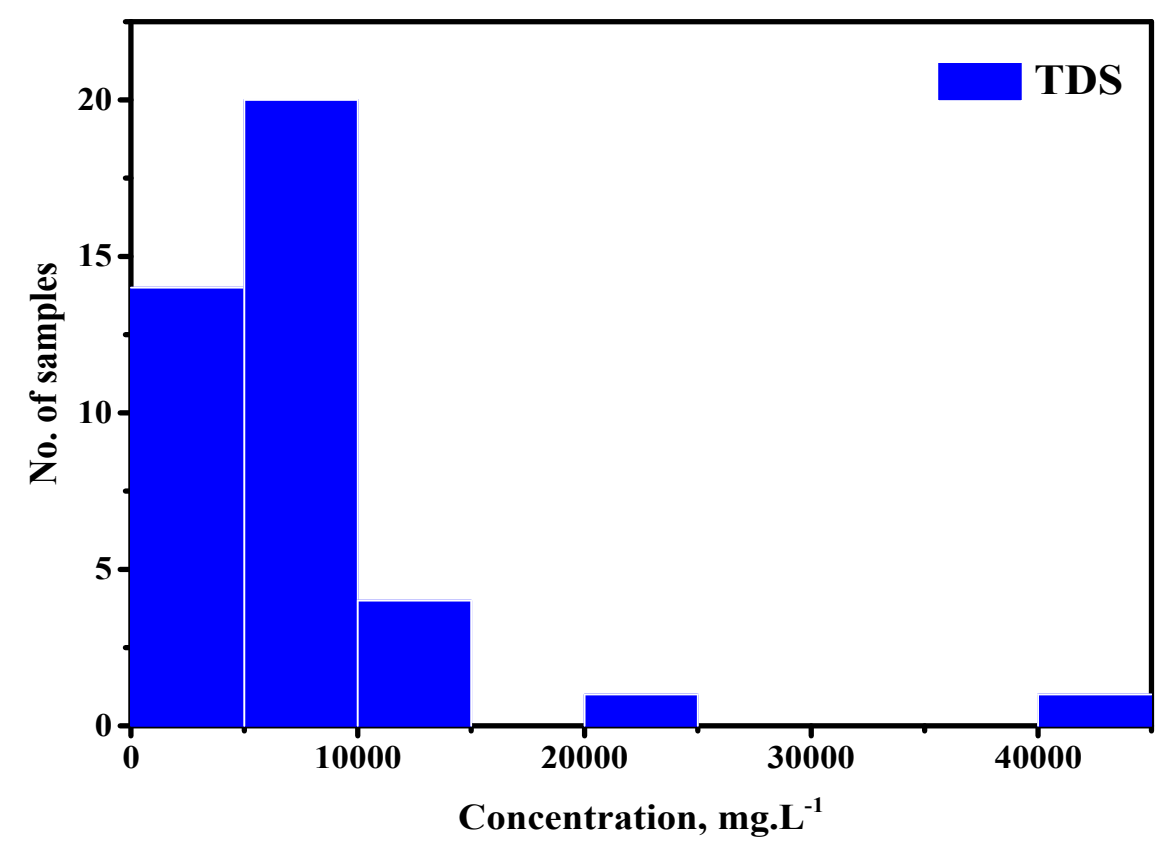

Fig. 5: Values of TDS vs. no. of groundwater samples collected from Ras Sudr area, Egypt.

The wide range of change in salinity $(2038-24383 \mathrm{mg} / \mathrm{l})$ may be due to the difference in the degree of effeteness of the different processes controlling the water salinity. For example, the water wells close to the Gulf of Suez shore are likely to be affected with seawater intrusion which can abruptly increase the salinity. Processes other than the seawater intrusion such as water-rock interactions and evaporation can increase the salinity gradually and with less amount of increase in salinity.

\subsubsection{Groundwater chemical type:}

According to the chemical analyses of groundwater samples collected from the Quaternary aquifer, the water chemical types are classified according to the dominant anions and cations into:

- Chloride - Sodium; characterizing $87 \%$ of samples.

- Sulfate - Calcium; characterizing $5 \%$ of samples. (Samples No. 36,37)

- Sulfate-Sodium; characterizing $5 \%$ of samples. (Samples No. 34,38)

- Chloride - Calcium; characterizing $3 \%$ of samples. (Sample No. 35)

Chloride - Sodium type prevails in the majority of groundwater samples. This reflects the role of seawater intrusion, leaching and dissolution processes of marine deposits in addition to the waterrock interactions. Meanwhile, seawater sample also has Cl-Na type.

\subsubsection{Hydrochemical coefficients (ionic ratios)}

Ionic ratios determine the relationship between the different major ions. The study of these ratios is helpful in detecting the hydrochemical processes affecting water quality (such as leaching, mixing, ion exchange) as well as detecting groundwater contamination or mixing with other water resources. They are used for establishing chemical similarities among waters representing a single aquifer, and they are helpful to evaluate the influence of seawater intrusion. The significance of these ratios in studying groundwater of Sudr area could be evaluated as follows (Tables 2 and 3): 
Table 2: Values of hydrochemical ratios of the groundwater samples collected from the Quaternary aquifer, Ras Sudr area, Egypt.

\begin{tabular}{|c|c|c|c|c|c|}
\hline Sample No. & $\mathrm{rNa}^{+} / \mathrm{rCl}^{-}$ & $\mathrm{rCa}^{2+} / \mathbf{r M g}^{2+}$ & $\mathrm{rSO}_{4}{ }^{2} / \mathrm{rCl}^{-}$ & $\mathrm{rCl}^{-} / \mathbf{r}\left(\mathrm{HCO}_{3}{ }^{-}+\mathrm{CO}_{3}{ }^{2-}\right)$ & $\mathrm{rCa} / \mathrm{r}\left(\mathrm{HCO}_{3}+\mathrm{SO}_{4}\right)$. \\
\hline 1 & 0.75 & 1.50 & 0.05 & 122.75 & 4.01 \\
\hline 2 & 0.76 & 1.29 & 0.16 & 63.20 & 1.49 \\
\hline 3 & 0.60 & 1.69 & 0.16 & 104.17 & 2.34 \\
\hline 4 & 0.75 & 0.39 & 0.17 & 61.66 & 0.59 \\
\hline 5 & 0.72 & 0.96 & 0.17 & 80.01 & 1.13 \\
\hline 6 & 0.83 & 1.42 & 0.35 & 38.43 & 0.78 \\
\hline 7 & 0.82 & 1.04 & 0.42 & 31.60 & 0.68 \\
\hline 8 & 0.74 & 1.33 & 0.41 & 46.60 & 1.00 \\
\hline 9 & 0.86 & 1.29 & 0.36 & 37.72 & 0.67 \\
\hline 10 & 1.06 & 1.15 & 0.70 & 16.04 & 0.44 \\
\hline 11 & 0.82 & 1.52 & 0.33 & 30.76 & 0.87 \\
\hline 12 & 0.85 & 1.32 & 0.75 & 12.27 & 0.65 \\
\hline 13 & 1.10 & 1.13 & 0.52 & 23.36 & 0.39 \\
\hline 14 & 0.78 & 1.21 & 0.14 & 25.03 & 1.12 \\
\hline 15 & 0.79 & 1.62 & 0.26 & 47.84 & 0.97 \\
\hline 16 & 0.96 & 0.78 & 0.25 & 65.63 & 0.47 \\
\hline 17 & 0.82 & 1.16 & 0.23 & 27.27 & 0.82 \\
\hline 18 & 0.97 & 1.06 & 0.34 & 35.55 & 0.50 \\
\hline 19 & 0.95 & 1.47 & 0.40 & 9.70 & 0.63 \\
\hline 20 & 1.14 & 1.06 & 0.46 & 14.73 & 0.42 \\
\hline 21 & 0.82 & 1.13 & 0.37 & 8.18 & 0.73 \\
\hline 22 & 0.78 & 1.21 & 0.25 & 39.13 & 0.90 \\
\hline 23 & 0.75 & 0.82 & 0.17 & 19.48 & 0.86 \\
\hline 24 & 0.88 & 0.99 & 0.27 & 24.83 & 0.60 \\
\hline 25 & 0.82 & 0.70 & 0.29 & 23.53 & 0.57 \\
\hline 26 & 0.92 & 0.98 & 0.50 & 16.25 & 0.52 \\
\hline 27 & 0.91 & 1.18 & 0.59 & 12.76 & 0.58 \\
\hline 28 & 0.80 & 0.94 & 0.35 & 31.51 & 0.66 \\
\hline 29 & 0.82 & 1.33 & 0.12 & 31.73 & 1.14 \\
\hline 30 & 0.59 & 1.07 & 0.26 & 25.88 & 1.38 \\
\hline 31 & 0.59 & 1.14 & 0.19 & 35.94 & 1.33 \\
\hline 32 & 0.60 & 1.11 & 0.20 & 34.01 & 1.25 \\
\hline 33 & 0.60 & 0.87 & 0.18 & 42.01 & 0.56 \\
\hline 34 & 1.04 & 1.68 & 1.05 & 5.30 & 1.04 \\
\hline 35 & 0.54 & 1.52 & 0.45 & 11.76 & 0.66 \\
\hline 36 & 0.79 & 1.55 & 1.00 & 5.63 & 0.64 \\
\hline 37 & 0.83 & 1.71 & 1.58 & 8.02 & 0.63 \\
\hline 38 & 0.91 & 1.62 & 1.09 & 7.29 & 0.72 \\
\hline 39 & 0.78 & 1.44 & 0.78 & 10.34 & 0.81 \\
\hline 40 & 0.61 & 1.29 & 0.67 & 26.48 & 0.37 \\
\hline seawater & 0.82 & 0.22 & 0.12 & 177.70 & 4.01 \\
\hline
\end{tabular}

Table 3: Ranges and mean values of hydrochemical ratios of water samples collected from the Quaternary aquifer, Ras Sudr area.

\begin{tabular}{lcc}
\hline Hydrochemical Ratio & Range & Mean \\
\hline $\mathbf{r N a}{ }^{+} / \mathbf{r C l}^{-}$ & $0.54-1.14$ & 0.81 \\
$\mathbf{r C a}^{2+} / \mathbf{M g g}^{2+}$ & $0.39-1.71$ & 1.21 \\
$\mathbf{r S O}{ }^{2-} / \mathbf{r C l}^{-}$ & $0.05-1.58$ & 0.43 \\
$\mathbf{r C l} / \mathbf{r}\left(\mathrm{HCO}_{3}{ }^{-+} \mathbf{C O}_{3}{ }^{2-}\right)$ & $5.3-122.75$ & 32.89 \\
$\mathbf{r C a}^{2+} / \mathbf{r}\left(\mathrm{HCO}_{3-} \mathbf{S O}_{4}{ }^{2-}\right)$ & $0.37-4.01$ & 0.89 \\
\hline
\end{tabular}

\subsubsection{Sodium / chloride ratio $\left(\mathrm{rNa}^{+} / \mathrm{rCl}^{-}\right)$}

The values of $\mathrm{rNa}^{+} / \mathrm{rCl}^{-}$ratio are ranging between 0.54 and 1.14 with a mean value of 0.81 (see tables 2 and 3). The values of $\mathrm{rNa}^{+} / \mathrm{rCl}^{-}$are always higher than unity in water of meteoric origin, while it is less than unity in seawater or water of marine origin (Hem 1989; Khaska et al., 2013). Most of the investigated groundwater samples $(90 \%)$ have values of $\mathrm{rNa}^{+} / \mathrm{rCl}^{-}$less than unity, i.e., they have 
$\mathrm{Cl}^{-}$concentration higher than that of $\mathrm{Na}^{+}$and they plotted above 1:1 equiline (Fig. 6), reflecting the leaching and dissolution of marine sediments in the Quaternary alluvial aquifer. The decrease in the concentration of $\mathrm{Na}^{+}$ions in these water samples may be attributed to the adsorption of sodium ions on the fine argillaceous sediments and mixing with marine water rich in chloride ions (Said 2004). The rest of samples $(10 \%)$ have values of $\mathrm{rNa}^{+} / \mathrm{rCl}^{-}$exceeding unity, i.e., they have $\mathrm{Na}^{+}$concentration higher than that of $\mathrm{Cl}^{-}$ions. The increase in the concentration of $\mathrm{Na}^{+}$ions in these water samples reflected meteoric water recharge or origin in addition to the dissolving of some terrestrial salts. The $\mathrm{rNa}^{+} / \mathrm{rCl}^{-}$ratio of seawater sample is $(0.82)$ which is less than unity, i.e., it has higher concentration of $\mathrm{Cl}^{-}$than $\mathrm{Na}^{+}$ions.

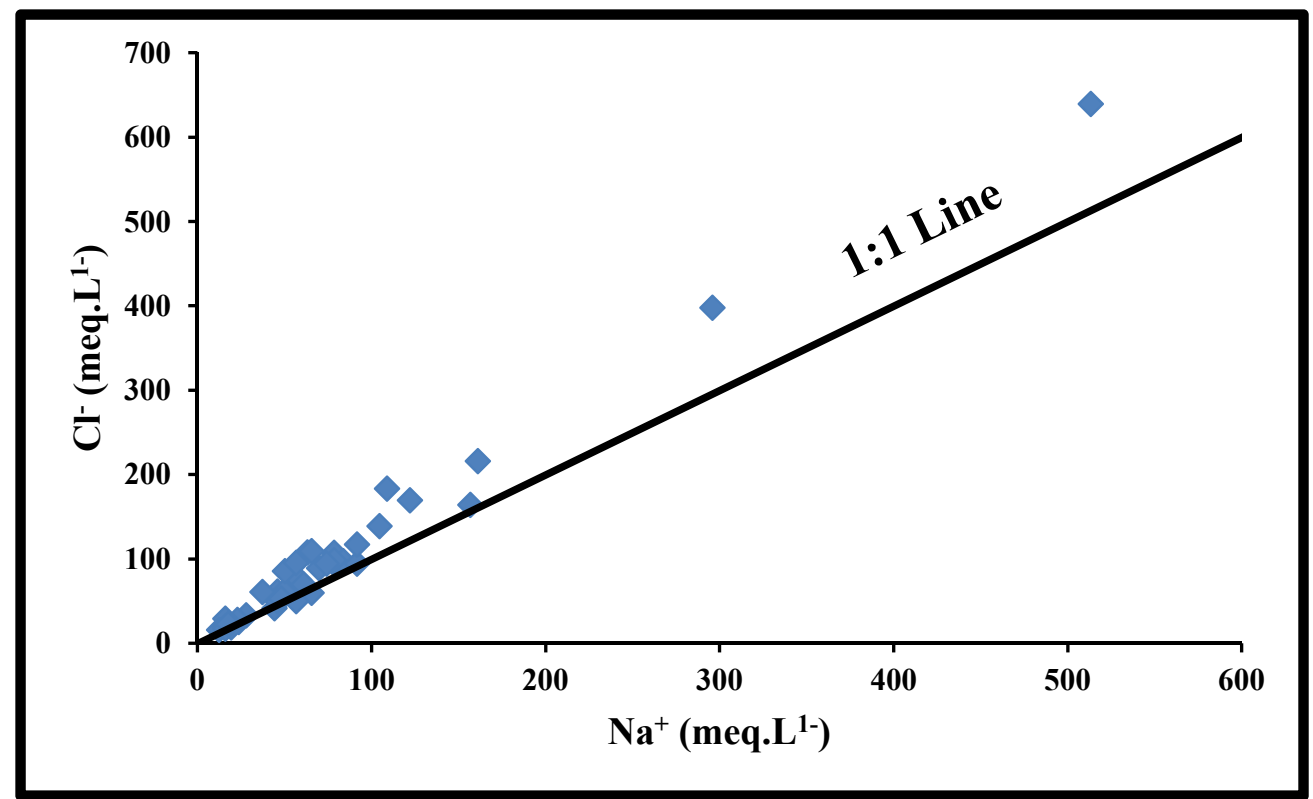

Fig. 6: Plot of $\mathrm{Na}^{+}$vs. $\mathrm{Cl}^{-}$for the groundwater samples collected from the Quaternary aquifer, Ras Sudr area, Egypt.

\subsubsection{Calcium/Magnesium ratio $\left(\mathrm{rCa}^{2+} / \mathrm{rMg}^{2+}\right)$}

Jacobson and Langmuir (1970) reported that the ratio $\mathrm{rCa}^{2+} / \mathrm{rMg}^{2+}$ give certain indications with regard to the nature of carbonate aquifers. When this ratio has a value close to unity, it is concluded that groundwater is flowing entirely through dolomite terrain $\left(\mathrm{Ca}, \mathrm{Mg}\left(\mathrm{CO}_{3}\right)_{2}\right)$. However, when the $\mathrm{rCa}^{2+} / \mathrm{rMg}^{2+}$ ratio is equal to or greater than unity, the groundwater is likely to have flowed in pure limestone (Meisler and Becher 1967). About $77 \%$ of groundwater samples have values of $\mathrm{rCa}^{2+} / \mathrm{rMg}^{2+}$ close to or exceeds unity and they fall above 1:1 equiline (Fig. 7) indicating that the groundwater of the Quaternary aquifer is flowing entirely through the limestone-dolomite terrain. This may also reflect the leaching of some terrestrial salts rich in calcium \& magnesium, and dissolution of gypsum in the Quaternary aquifer environment. On the other hand, $23 \%$ of groundwater samples have $\mathrm{rCa}^{2+} / \mathrm{rMg}^{2+}$ ratio less than unity, this means magnesium ions concentration exceed that of calcium ions. This is confirmed by the precipitation of calcium carbonate or calcium sulfate in the pore space of rocks-forming the aquifer matrix due to the long path of water flow (Hem 1989). This also indicates sea water intrusion and active ion exchange processes between calcium and magnesium with sodium. 


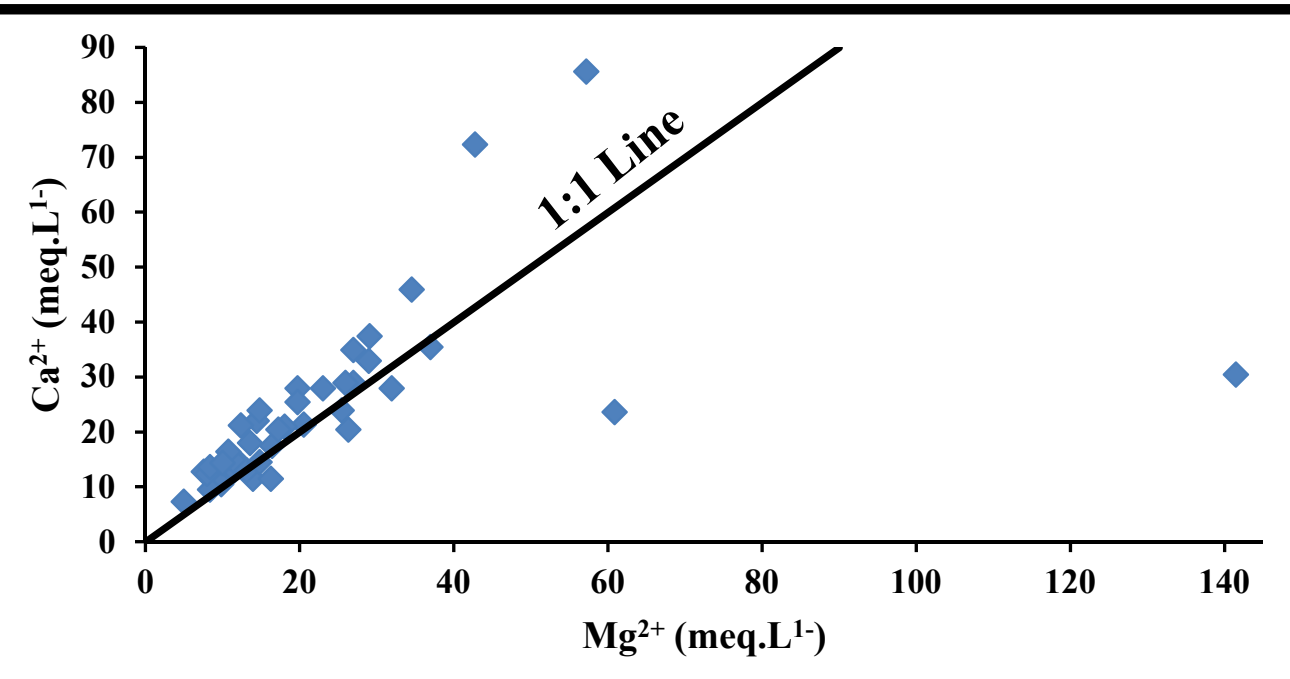

Fig. 7: Plot of $\mathrm{Ca}^{2+}$ vs. $\mathrm{Mg}^{2+}$ for the groundwater samples collected from the Quaternary aquifer, Ras Sudr area, Egypt.

\subsubsection{Sulfate/ chloride ratio $\left(\mathrm{rSO}_{4}{ }^{2-} / \mathrm{rCl}^{-}\right)$}

This ratio (Fig 8) could be taken as a guide for detecting any excess of sulfate ions in groundwater due to gypsum $\left(\mathrm{CaSO}_{4} \cdot 2 \mathrm{H}_{2} \mathrm{O}\right)$ dissolution or calcite $\left(\mathrm{CaCO}_{3}\right)$ precipitation. The majority of groundwater samples ( $97 \%$ ) have values of this ratio more than that of seawater $(0.12)$. This may indicate the solution of a local terrestrial source of sulfates such as gypsum, anhydrite, glauberite $\left(\mathrm{Na}_{2} \mathrm{SO}_{4} \cdot 10 \mathrm{H}_{2} \mathrm{O}\right)$ and epsomite $\left(\mathrm{MgSO}_{4} \cdot 7 \mathrm{H}_{2} \mathrm{O}\right)$. Only one sample (No. 1) has a value of 0.05 for $\mathrm{rSO}_{4}{ }^{2-} / \mathrm{rCl}^{-}$which is less than the value of this ratio for seawater (0.12). This indicates that the source of $\mathrm{SO}_{4}{ }^{2-}$ is the marine deposits in the aquifer matrix. This ratio can also be used to distinguish modern sea-water intrusion from previous intrusion in waters having chloride concentrations greater than 500 $\mathrm{mg} / \mathrm{l}$, as done by Pomper (1981) in the Netherlands. As a result of sulfate reduction, older saline waters are characterized by $\mathrm{Cl} / \mathrm{SO}_{4}$ ratios that are higher than those found in modern seawater.

\subsubsection{Chloride/ bicarbonate and carbonate ratio $\left.\mathrm{rCl}^{-} / \mathrm{r}_{\left(\mathrm{HCO}_{3}\right.}{ }^{-}+\mathrm{CO}^{2-}\right)$}

According to El Moujabber et al., (2006), the study of this ratio is useful to separate trends of salinization and the areas affected by seawater intrusion. Simpson (1946) classified groundwater according to this ratio into the following categories: normal good water (less than 1), slightly contaminated water (more than 1 and less than 2), moderately contaminated water (2-6), seriously contaminated water (6-15) and, highly contaminated water (more than 15). The $\mathrm{rCl} / \mathrm{r}\left(\mathrm{HCO}_{3}^{-}+\mathrm{CO}_{3}{ }^{2-}\right)$ ratio increases as the total water salinity increases, indicating highly saline water contamination, while the decreasing values are found due to continuous fresh water dilution or recharge. Most of the groundwater samples $(72 \%)$ have values of this ratio more than 15 , indicating highly contaminated water, while $23 \%$ of samples are seriously contaminated water, and some groundwater samples $(5 \%)$ are moderately contaminated (see tables 2 and 3). Consequently, all groundwater samples constitute contaminated water, to a less or more extent, by marine salts and the groundwater has a meteoric origin that is possibly infiltration of pure meteoric water affected by marine deposits or seawater intrusion. Furthermore, the seawater sample has the highest value of this ratio (177.7) because of its high salinity and high chloride content. 


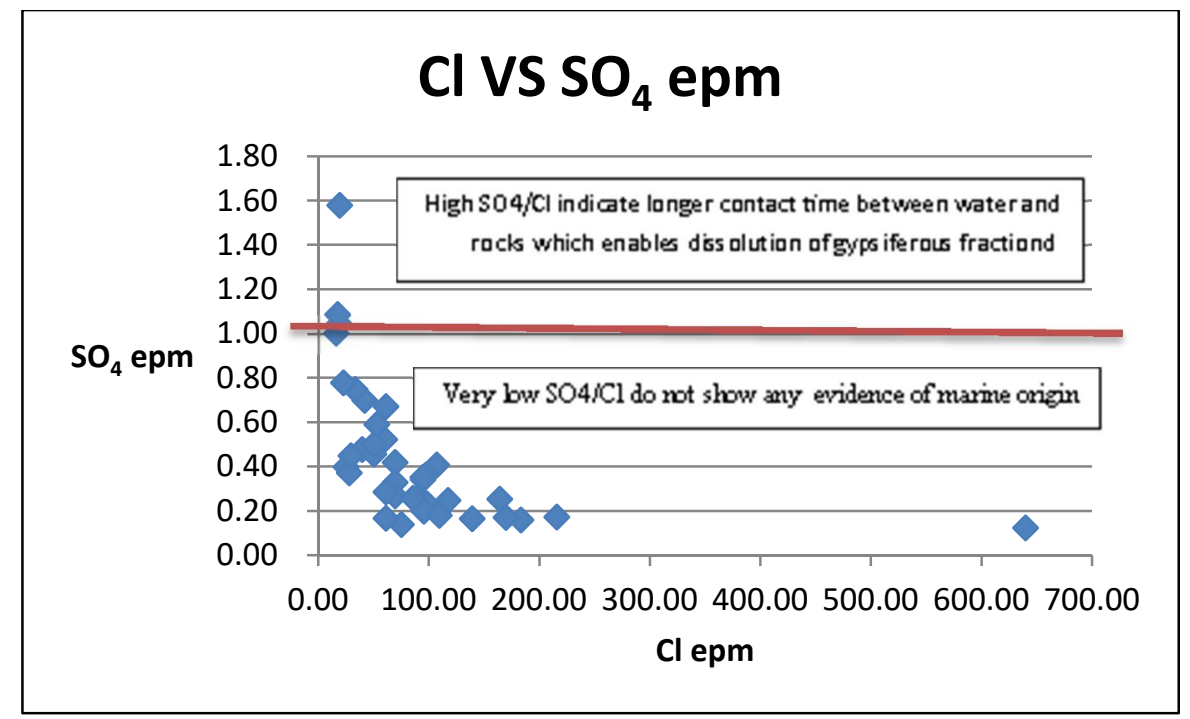

Fig. 8: Scatter plot of $\mathrm{rCl} \mathrm{VS} \mathrm{rSO}_{4}(\mathrm{epm})$ for groundwater samples collected from the Quaternary aquifer, Ras Sudr area, Egypt.

\subsubsection{5. $\mathrm{rNa} / \mathrm{rCl}$ versus $\mathrm{rCa} / \mathrm{r}\left(\mathrm{HCO}_{3}+\mathrm{SO}_{4}\right)$}

The $\mathrm{rNa} / \mathrm{rCl}$ versus $\mathrm{rCa} / \mathrm{r}\left(\mathrm{HCO}_{3}+\mathrm{SO}_{4}\right)$ plot (Fig. 9) indicates that a large portion of the groundwater samples $(62 \%)$ fall in the saline region $\left(\mathrm{Cl}^{-}\right.$-excess) referring to the seawater influence on the aquifer (i.e, seawater intrusion, Abdalla 2016). About (10\%) of samples plotted in the base exchange region, while the rest of the samples $(28 \%)$ fall in the $\left(\mathrm{Ca}^{2+}\right.$-excess) region. When the ratio, $\mathrm{Ca} /\left(\mathrm{HCO}_{3}+\mathrm{SO}_{4}\right)$ is greater than 1 , this indicates active intrusion and ion exchange reactions are significant. If the ratio is less than 1 but chloride concentration is more than $1000 \mathrm{mg} / \mathrm{L}$, then the well has been previously intruded and may be in equilibrium with seawater (Prinos et al., 2014). Enrichment of $\mathrm{Ca}^{2+}$ can indicate seawater intrusion (Bear, et al., 1999). Enrichment is reflected in $\mathrm{Ca} / \mathrm{Mg}>1$ and $\mathrm{Ca}^{2+} /\left(\mathrm{HCO}_{3}{ }^{-}+\mathrm{SO}_{4}{ }^{2-}\right)>1$. Saline water with high $\mathrm{Ca}^{2+}$ can originate by a different mechanism, not necessary related to base-exchange reaction and modification of modern seawater.

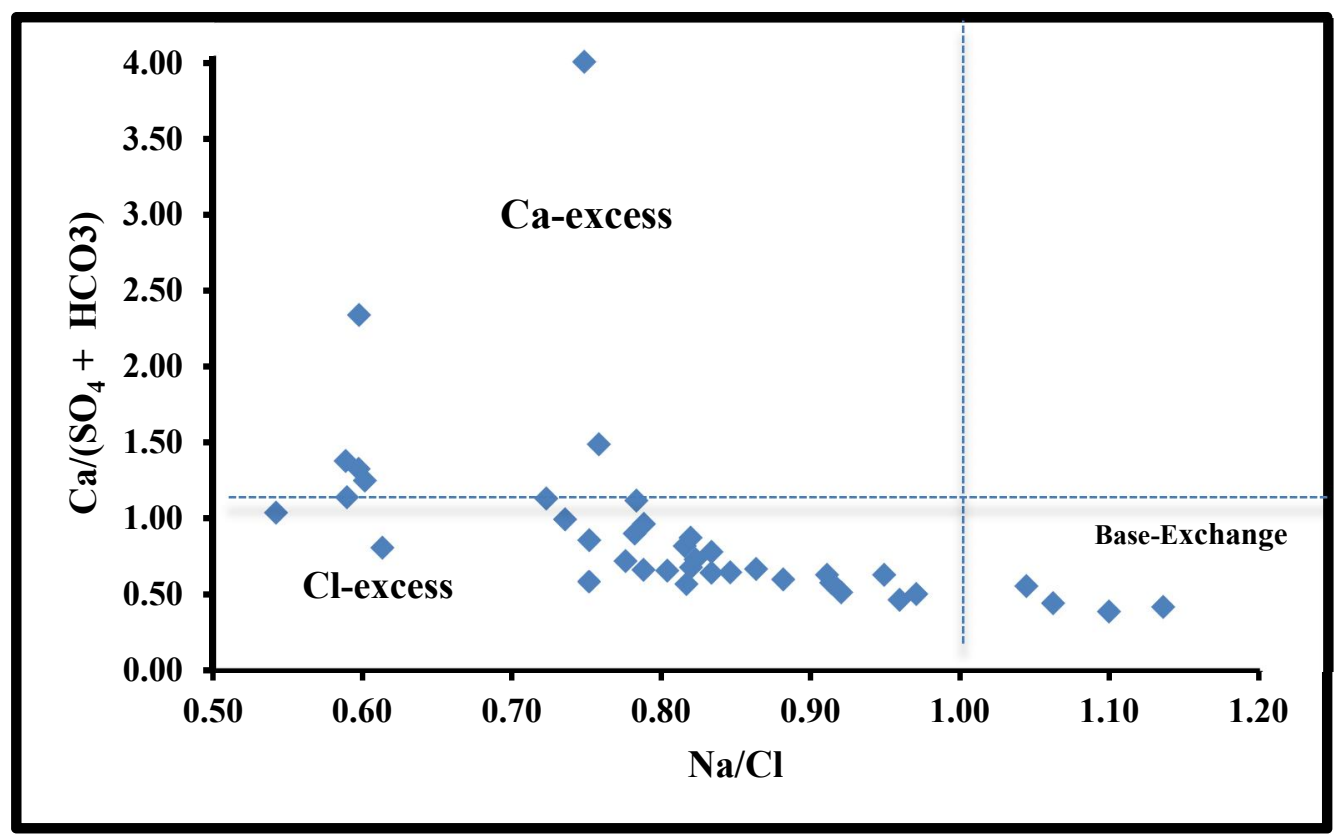

Fig. 9: Scatter plot of $\mathrm{Na} / \mathrm{Cl} \mathrm{Vs} \mathrm{Ca} /\left(\mathrm{SO}_{4}+\mathrm{HCO}_{3}\right)$ for groundwater samples collected from the Quaternary aquifer, Ras Sudr area, Egypt. 


\subsection{Geochemical classification of groundwater}

Many methods have been proposed by different authors for the geo-chemical classification of groundwater samples. Some of these methods are based mainly on the use of anions, while the others are based on both anions and cations. The exchange of $\mathrm{Ca}^{2+}$ and $\mathrm{Na}^{+}$between the aquifer matrix and intruding seawater is well displayed in Chadha and Piper plots as follows:

\subsubsection{Chadha's diagram}

Chadha (1999) proposed a diagram that helps in developing and understanding the waterquality data, because it satisfies the basic requirement for a suitable classification of natural waters, and it also can be effectively used in the study of the hydrochemical processes. Chadha's diagram (Fig. 10) revealed that the majority of groundwater samples collected from the Quaternary aquifer fall in the zone of seawater ( $\mathrm{Na}-\mathrm{Cl}$ water type), where the alkali metals exceed the alkaline earth metals and strong acidic anions exceed weak acidic anions. The plot of these samples at the zone of seawater is found to be an indication for the predominance of seawater influence into the aquifer. The rest of the samples fall in the zone of reverse ion exchange water $(\mathrm{Ca} / \mathrm{Mg}-\mathrm{Cl}$ water type) where alkaline earth metals exceed the alkali metals and strong acidic anions exceed weak acidic anions. This reverse ion exchange process is also seen as indicative of active seawater intrusion into the Quaternary aquifer. Hydrogeochemical properties of groundwater based on Chadha's diagram show that saline groundwater conditions are possibly attributed mainly to the seawater intrusion and the reverse ion exchange reactions inside the aquifer environment. The insignificant role of groundwater recharge is because of the low seasonal rainfall in Sudr area.

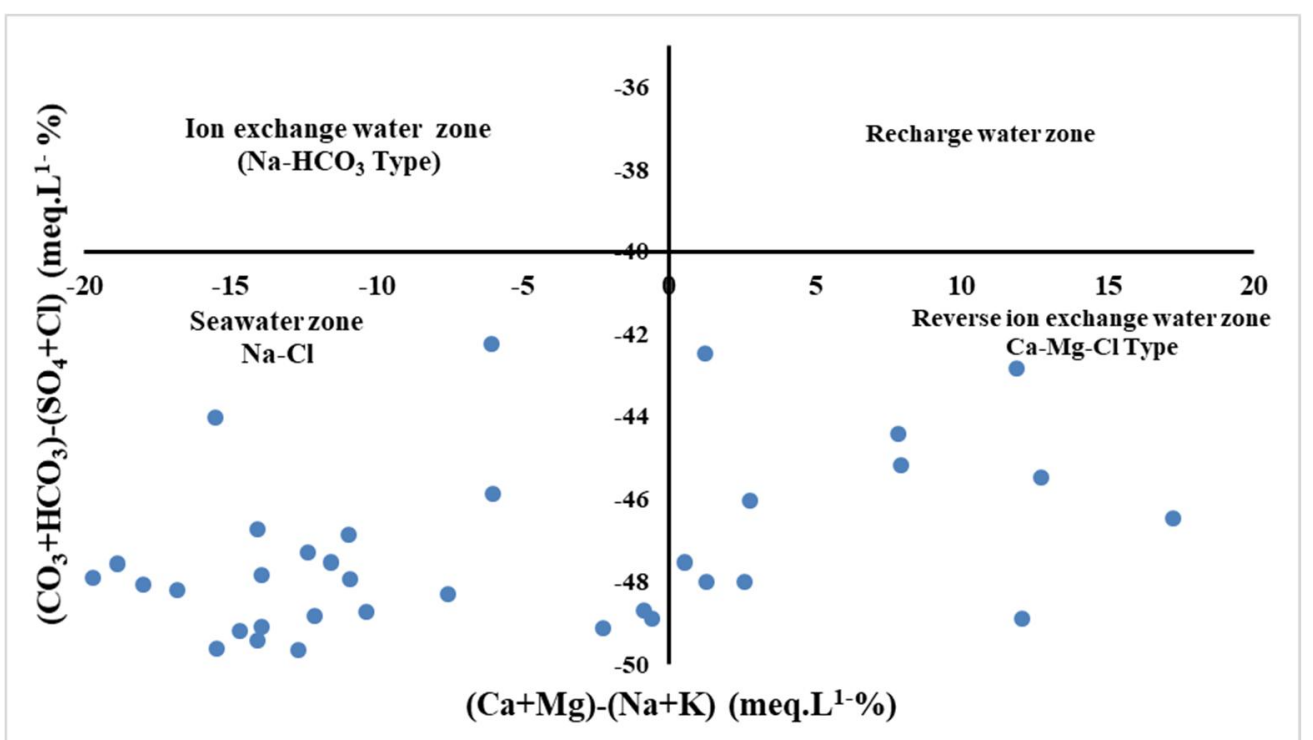

Fig. 10: Chadha's classification for the water samples collected from the Quaternary aquifer, Ras Sudr area, Egypt.

\subsubsection{Piper's tri-linear diagram}

The Piper's trilinear diagram is widely used to compare numerous water analyses (Piper, 1953). The chemical analyses of groundwater plotted on Piper's diagram (Fig. 11) show that $75 \%$ of collected groundwater samples are located in the sub-area 7, where the groundwater samples are dominated by noncarbonated alkali and strong acids (Primary salinity exceeds 50 percent and the dominant water type is $\mathrm{Na}-\mathrm{Cl}$ ). About $15 \%$ of the groundwater samples are located in sub area 6 , where non-carbonate hardness is dominant (secondary salinity exceeds 50 percent and the dominant water type is $\mathrm{Ca}-\mathrm{Cl}$ ). Only $10 \%$ of groundwater samples are located in sub-area 9 where no one cation-anion pair exceeds 50 percent and the dominant water type is $\mathrm{Ca}-\mathrm{Mg}-\mathrm{Cl}$ (mixed zone). Noteworthy to mention that samples located within sub-area 7 are shown to be more influenced by seawater intrusion or marine salts, while those located in sub-areas 6 and 9 are more affected by direct rainfall as well as surface and subsurface runoff recharges. Thus, the Quaternary groundwater is 
mainly affected by marine (sub-area 7) and partially affected by continental facies (sub-areas 6 and 9) as a result of leaching and dissolution of marine and terrestrial salts, respectively (Said, 2004).

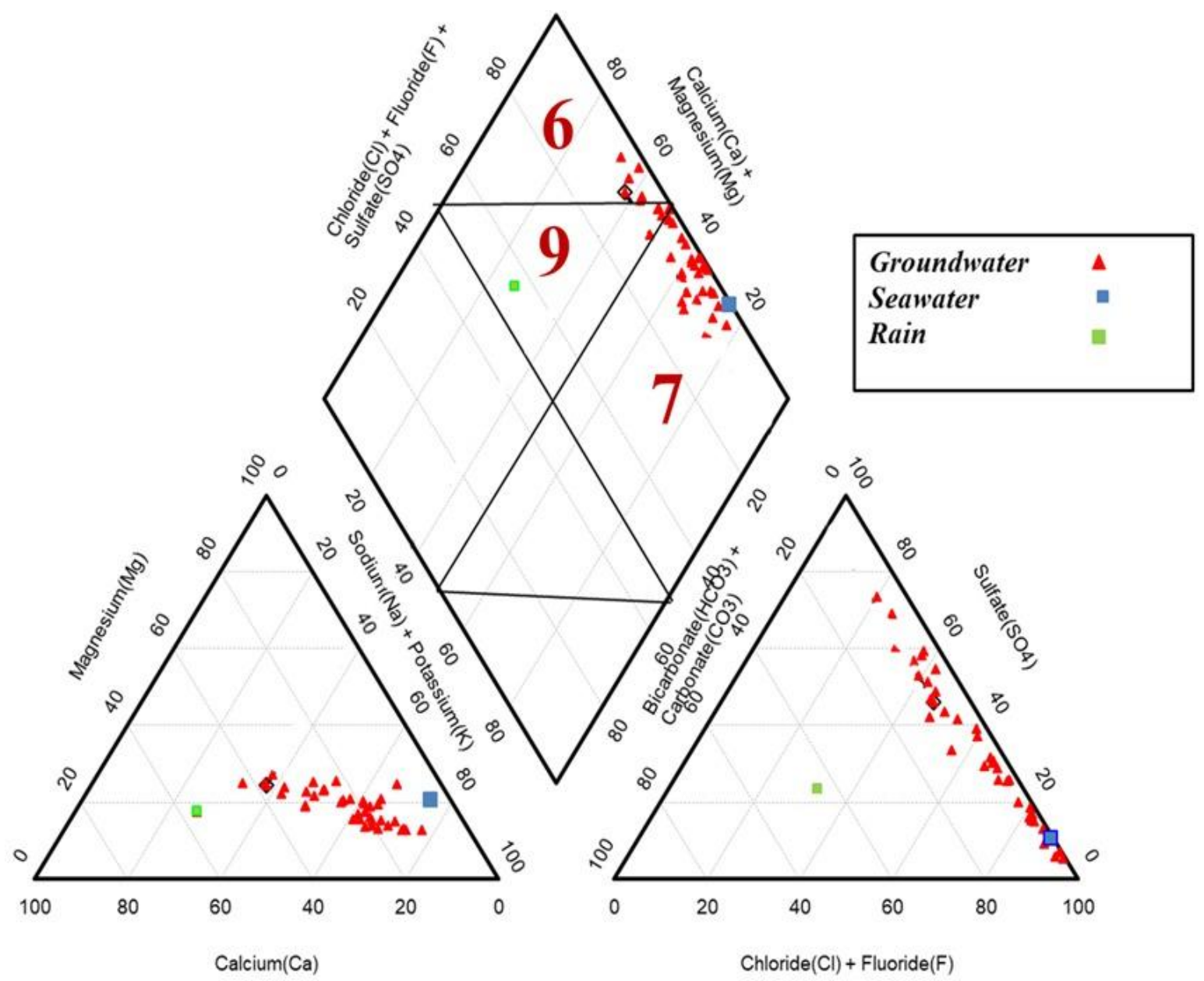

Fig. 11: Piper tri-linear diagram of major chemical compositions of groundwater samples collected from Ras Sudr area, Egypt.

\subsection{Hydrogeochemical processes affecting groundwater quality \\ 4.3.1. Leaching and dissolution processes}

The Leaching and dissolution processes could be studied through the determination of multiple ionic ratios (Gibbs diagram) and saturation indices (SI).

\subsubsection{Gibbs's cationic ratio}

Gibbs's diagram is constructed to show the hydrochemical processes (precipitation, water-rock interaction, and evaporation) affecting groundwater composition (Gibbs 1970). Minerals formation or solubility in groundwater is affected by evaporation or dissolution process. Evaporation process mainly occurred in the surface layers and resulted in a strongly negative water balance, which resulted in the accumulation of salts in the top soil. This soil water became more mineralized and later on, carried down a great amount of the accumulated salts dissolved by rainfall to the water table. TDS values are plotted against major cations $\left(\mathrm{Na}^{+}+\mathrm{K}^{+} / \mathrm{Na}^{+}+\mathrm{K}^{+}+\mathrm{Ca}^{2+}\right)$ in Fig. 12. The plot indicated that most groundwater samples of Quaternary aquifer are located near the upper end of the boomerang indicate evaporation process, increase of the TDS value and $\mathrm{Na}^{+}$concentration in water as well as decrease of $\mathrm{Ca}^{2+}$ concentration. Furthermore, leaching and dissolution of saline deposits and overpumping activities can be considered as the second factor in concentration and salinization processes. The groundwater samples located in the center of the boomerang are influenced by water rock interaction. 


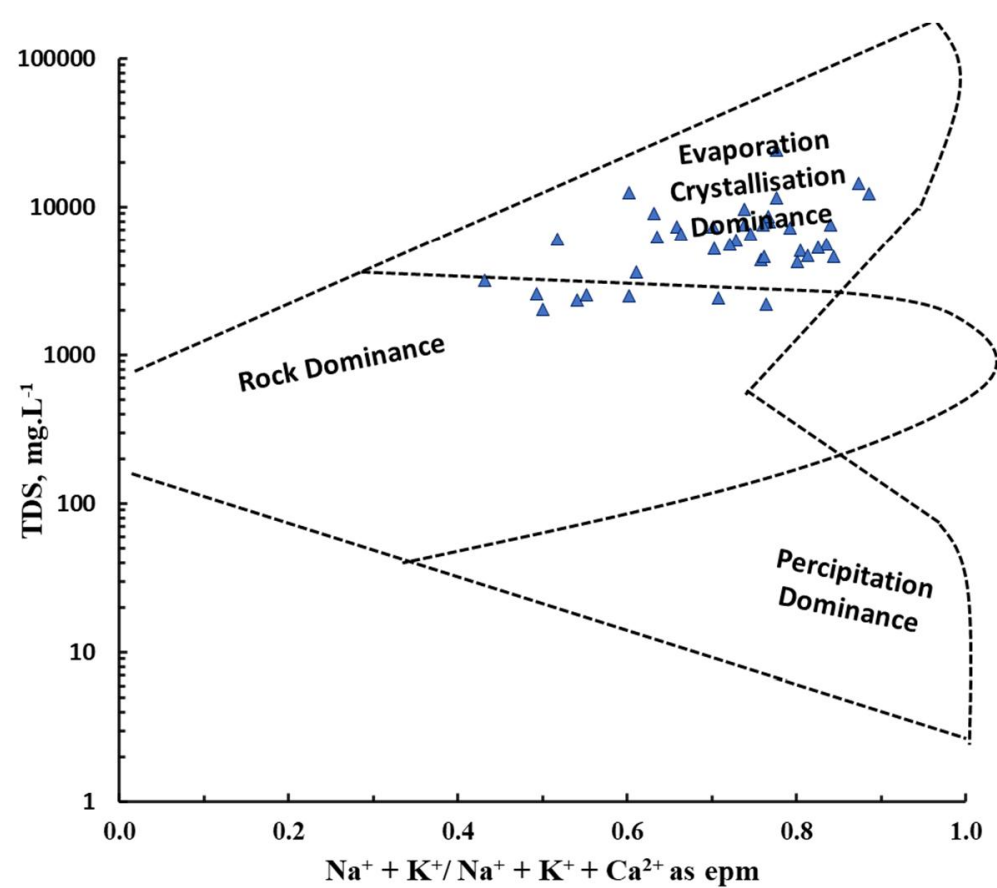

Fig. 12: Gibbs plot for groundwater samples collected from the Quaternary aquifer, Ras Sudr area, Egypt.

\subsubsection{Chemical equilibrium and saturation indices (SI)}

The quality of water and its interactions with soils and host rocks during its percolation, movement, and storage in the aquifers represented the key factors in the water chemistry. These interactions involved mainly the chemical reactions of dissolution and precipitation processes, which are controlled by the solubility products of different involved mineral phases. The degree of water saturation with respect to a mineral (SI) is given by the equation (1), Langelier (1936).

$\mathrm{SI}=\log \left(\mathrm{K}_{\mathrm{IAP}} / \mathrm{K}_{\mathrm{SP}}\right)$

Where, $\mathrm{K}_{\mathrm{IAP}}$ is the ionic activity product, $\mathrm{K}_{\mathrm{SP}}$ is the solubility product and $\mathrm{SI}$ is the saturation index of the concerned mineral.

When SI is equal to zero, the water is at equilibrium or saturated with the mineral phase, SI value less than zero (negative value) pointed to under-saturation and the mineral phase tended to dissolve, whereas SI value over zero (positive value) showed super-saturation and the mineral phase tended to precipitate. The saturation indices (SI) of the major mineral phases in the investigated groundwater samples were calculated using the software package (NETPATH-WIN), Plummer et al., (1994). The obtained results are represented and shown in Table (4) and figures (13 and 14). The SI calculations reflect the following:

1. Most of the groundwater samples are oversaturated or nearly in equilibrium with respect to aragonite, calcite and dolomite. This was clear where the $\mathrm{pH}$ values reflected slightly alkaline character.

2. Seawater sample has positive saturation indices for aragonite, calcite and, dolomite indicating super-saturation with carbonate minerals.

3. Seawater and all groundwater samples have negative SI for gypsum and anhydrite, indicating that, the groundwater samples are below the saturation state with these sulfate minerals. The dissolution of gypsum can be expressed in the following equation (2):

$\mathrm{CaSO}_{4} \leftrightarrow \mathrm{Ca}^{2+}+\mathrm{SO}_{4}^{2-}$

Gypsum dissolution resulted in an increase of $\mathrm{Ca}^{2+}$ concentration which causes calcite to precipitate. However, the dissolution of gypsum induces the transformation of dolomite to calcite in the sediments and produced water with high $\mathrm{Mg}^{2+}, \mathrm{Ca}^{2+}$ and $\mathrm{SO}_{4}{ }^{2-}$ concentrations (Apello and Postama, 2005). 

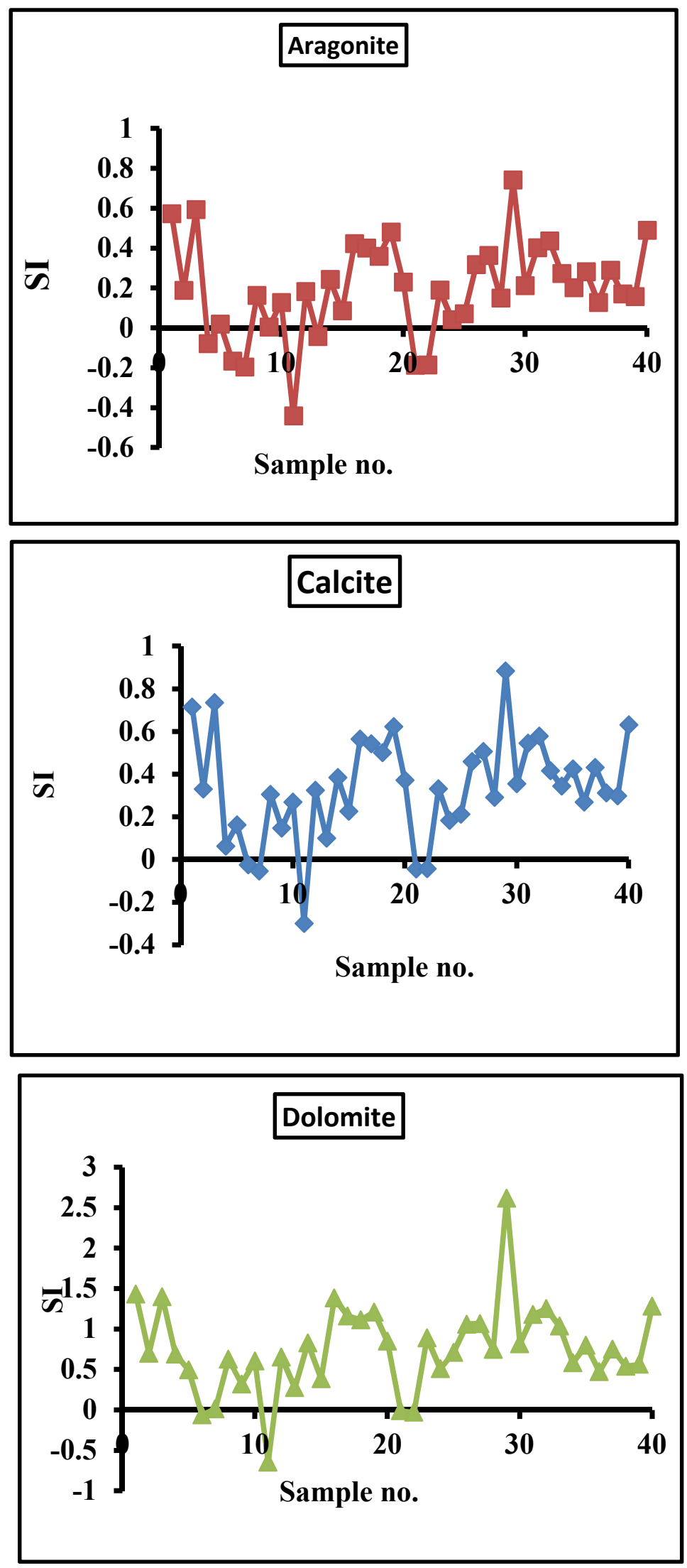

Fig. 13: Saturation indices of carbonate minerals for groundwater samples collected from the Quaternary aquifer, Ras Sudr area, Egypt. 
Curr. Sci. Int., 10(4): 599-622, 2021

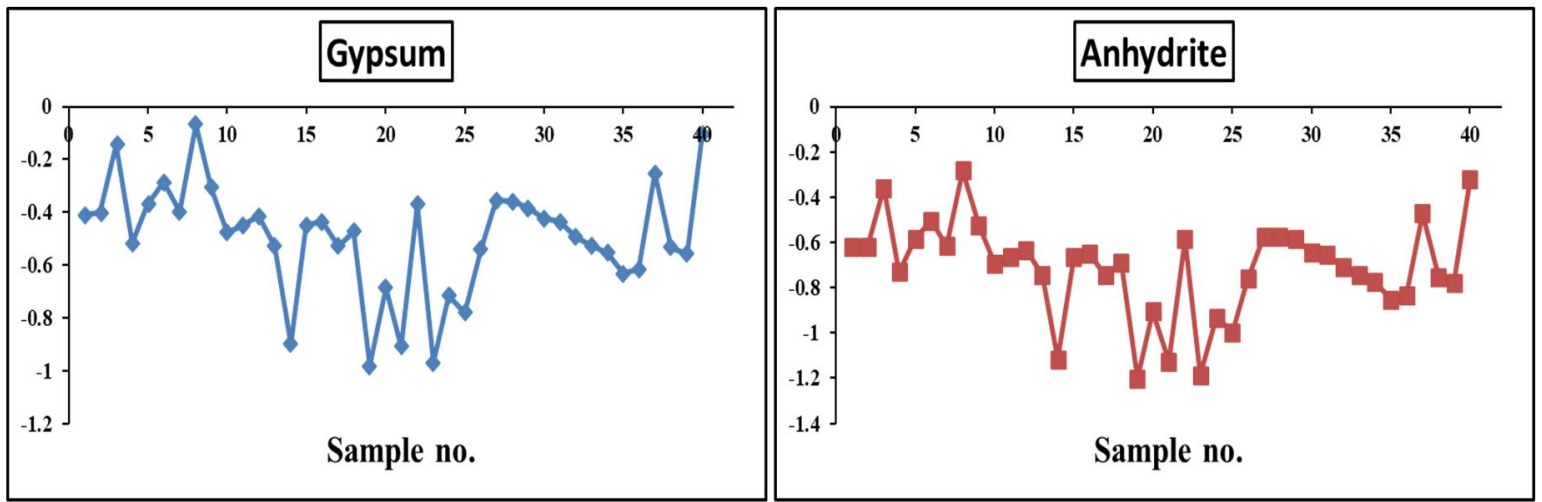

Fig. 14: Saturation indices of sulfate minerals for groundwater samples collected from the Quaternary aquifer, Ras Sudr area, Egypt

Table 4: Values of saturation indices of water samples collected from the Quaternary aquifer, Ras Sudr area, Egypt.

\begin{tabular}{|c|c|c|c|c|c|}
\hline \multirow{2}{*}{ Sample no. } & \multicolumn{3}{|c|}{ Carbonate Minerals } & \multicolumn{2}{|c|}{ Sulfate Minerals } \\
\hline & Calcite & Aragonite & Dolomite & Gypsum & anhydrite \\
\hline 1 & 0.715 & 0.572 & 1.432 & -0.41 & -0.619 \\
\hline 2 & 0.331 & 0.188 & 0.701 & -0.403 & -0.618 \\
\hline 3 & 0.736 & 0.593 & 1.398 & -0.145 & -0.36 \\
\hline 4 & 0.064 & -0.08 & 0.691 & -0.517 & -0.731 \\
\hline 5 & 0.163 & 0.019 & 0.494 & -0.37 & -0.585 \\
\hline 6 & -0.023 & -0.167 & -0.062 & -0.288 & -0.505 \\
\hline 7 & -0.053 & -0.196 & 0.012 & -0.399 & -0.616 \\
\hline 8 & 0.306 & 0.163 & 0.627 & -0.067 & -0.283 \\
\hline 9 & 0.148 & 0.004 & 0.32 & -0.306 & -0.523 \\
\hline 10 & 0.27 & 0.127 & 0.606 & -0.478 & -0.696 \\
\hline 11 & -0.298 & -0.442 & -0.646 & -0.449 & -0.667 \\
\hline 12 & 0.326 & 0.182 & 0.654 & -0.415 & -0.634 \\
\hline 13 & 0.101 & -0.043 & 0.276 & -0.528 & -0.746 \\
\hline 14 & 0.386 & 0.242 & 0.828 & -0.9 & -1.117 \\
\hline 15 & 0.228 & 0.085 & 0.384 & -0.449 & -0.666 \\
\hline 16 & 0.566 & 0.423 & 1.384 & -0.436 & -0.651 \\
\hline 17 & 0.543 & 0.4 & 1.162 & -0.529 & -0.746 \\
\hline 18 & 0.502 & 0.358 & 1.112 & -0.473 & -0.69 \\
\hline 19 & 0.624 & 0.48 & 1.21 & -0.983 & -1.202 \\
\hline 20 & 0.373 & 0.229 & 0.849 & -0.687 & -0.905 \\
\hline 21 & -0.043 & -0.187 & -0.01 & -0.908 & -1.127 \\
\hline 22 & -0.042 & -0.186 & -0.028 & -0.371 & -0.587 \\
\hline 23 & 0.333 & 0.189 & 0.889 & -0.969 & -1.187 \\
\hline 24 & 0.184 & 0.041 & 0.509 & -0.715 & -0.933 \\
\hline 25 & 0.214 & 0.07 & 0.713 & -0.779 & -0.997 \\
\hline 26 & 0.46 & 0.317 & 1.059 & -0.542 & -0.76 \\
\hline 27 & 0.507 & 0.363 & 1.068 & -0.356 & -0.574 \\
\hline 28 & 0.293 & 0.149 & 0.748 & -0.36 & -0.577 \\
\hline 29 & 0.899 & 0.755 & 1.817 & -0.86 & -1.077 \\
\hline 30 & 0.356 & 0.212 & 0.819 & -0.424 & -0.644 \\
\hline 31 & 0.546 & 0.402 & 1.178 & -0.436 & -0.653 \\
\hline 32 & 0.579 & 0.435 & 1.252 & -0.493 & -0.71 \\
\hline 33 & 0.417 & 0.273 & 1.036 & -0.527 & -0.744 \\
\hline 34 & 0.345 & 0.201 & 0.584 & -0.553 & -0.772 \\
\hline 35 & 0.426 & 0.282 & 0.8 & -0.633 & -0.852 \\
\hline 36 & 0.271 & 0.127 & 0.475 & -0.615 & -0.834 \\
\hline 37 & 0.433 & 0.289 & 0.75 & -0.253 & -0.473 \\
\hline 38 & 0.314 & 0.17 & 0.541 & -0.532 & -0.752 \\
\hline 39 & 0.299 & 0.156 & 0.565 & -0.558 & -0.778 \\
\hline 40 & 0.632 & 0.489 & 1.281 & -0.104 & -0.322 \\
\hline Seawater & 0.885 & 0.742 & 2.619 & -0.386 & -0.587 \\
\hline
\end{tabular}




\subsubsection{Ion exchange}

Ion exchange is responsible for the concentration of ions in groundwater. Schoeller (1965) suggested two chloro-alkaline indices (CAI) to indicate the exchange of ions between groundwater and its host environment. These indices are expressed in meq. $\mathrm{L}^{-1}$ and they are represented by the following equations $(3 \& 4)$ :

$\mathrm{CAI}_{1}=\mathrm{Cl}^{-}-\left(\mathrm{Na}^{+}+\mathrm{K}^{+}\right) / \mathrm{Cl}^{-}$

$\mathrm{CAI}_{2}=\mathrm{Cl}^{-}-\left(\mathrm{Na}^{+}+\mathrm{K}^{+}\right) /\left(\mathrm{SO}_{4}{ }^{2-}+\mathrm{HCO}_{3}{ }^{-}+\mathrm{CO}_{3}{ }^{2-}\right)$

The values of the two indices are positive if there is an exchange of $\mathrm{Na}^{+} \& \mathrm{~K}^{+}$from the water with $\mathrm{Mg}^{2+} \& \mathrm{Ca}^{2+}$ of the host rocks (the aquifer matrix) and negative when there is an exchange of $\mathrm{Mg}^{2+} \& \mathrm{Ca}^{2+}$ of the water with $\mathrm{Na}^{+} \& \mathrm{~K}^{+}$of the host rocks. Figure (15) shows the values of the two indices, where $87 \%$ of the water samples have positive CAI values, reflecting that $\mathrm{Na}^{+} \& \mathrm{~K}^{+}$from water are exchanged with $\mathrm{Mg}^{2+} \& \mathrm{Ca}^{2+}$ in the host rock. On the other hand, CAI values are noted in 13 $\%$ of the investigated samples (No. 10, 13, 20,34) showing that, $\mathrm{Mg}^{2+} \& \mathrm{Ca}^{2+}$ from water are exchanged with $\mathrm{Na}^{+} \& \mathrm{~K}^{+}$in the aquifer matrix.

Recent sea-water intrusion would be expected to be associated with data points predominantly showing ion exchange, whereas old sea-water intrusion would be expected to include many data points with little or no evidence of ion exchange (Howard and Lloyd, 1983). These ion exchange processes occur in a portion of the saltwater front called the ion-exchange front, and may include exchange of sodium in seawater with adsorbed calcium; adsorption of potassium, boron, and lithium in seawater onto clay minerals (Jones et al., 1999); enrichment in calcium and bicarbonate caused by dissolution of calcite and aragonite in carbonate aquifers (Richter and Kreitler, 1993; Jones et al., 1999); reduction of the sulfate in seawater to hydrogen sulfide under low redox conditions in the aquifer (Richter and Kreitler, 1993; Jones et al., 1999); and exchange of calcium adsorbed on clay minerals with magnesium in seawater (Howard and Lloyd, 1983; Richter and Kreitler, 1993).

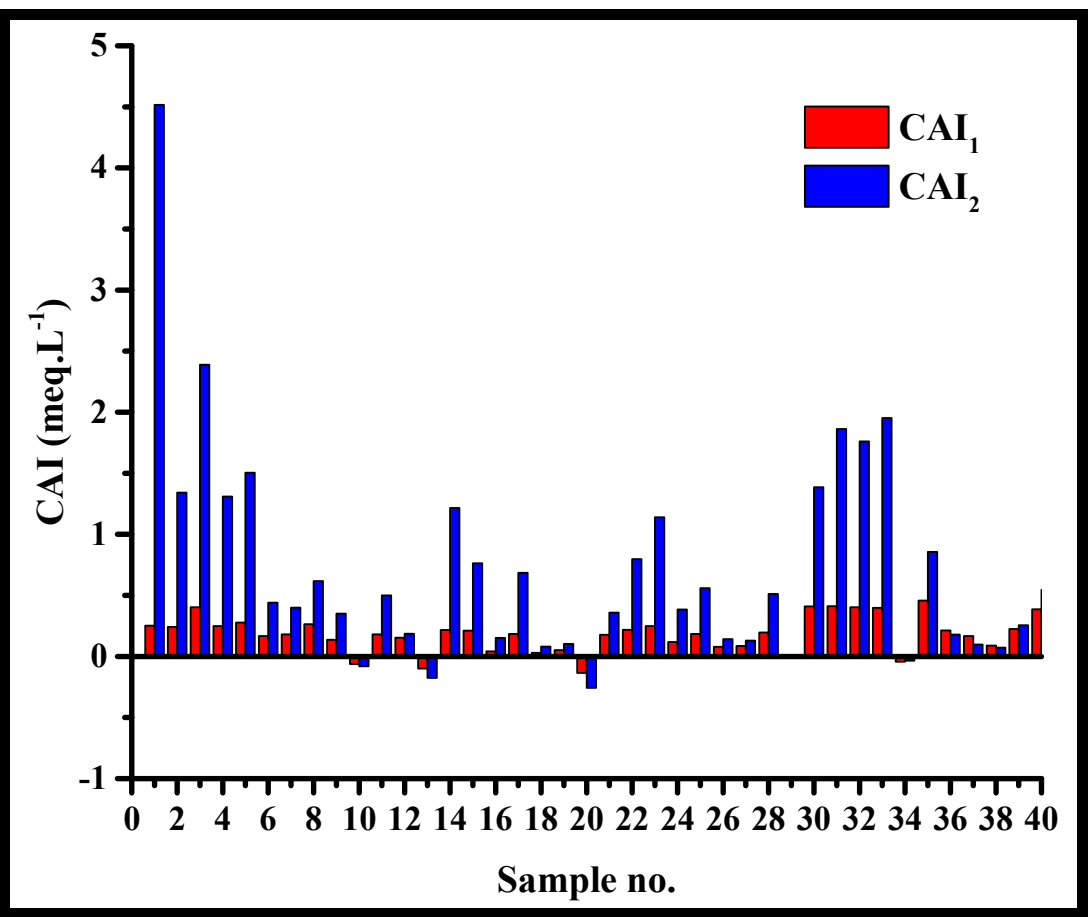

Fig. 15: Bar diagram showing Chloro Alkaline Indices for groundwater samples collected from Ras Sudr area, Egypt.

\subsubsection{Seawater intrusion (encrochment)}

\subsubsection{Seawater fraction $(f)$ in groundwater samples}

The seawater fraction has been calculated based on chloride concentration (expressed in meq.L-

${ }^{1}$ ) because chloride is assumed to be a conservative tracer since it is not involved at many geochemical 
processes (Appelo and Postama 2005). The seawater fraction has been calculated based on equation (5):

$f_{\text {seawater }}=\frac{C_{c l \text {-sample }}-C_{c l-\text { fresh }}}{C_{c l \text {-sea }}-C_{c l-\text { fresh }}} \%$.

Where $C_{C l \text {-sample }}$ is the $\mathrm{Cl}^{-}$concentration of the groundwater sample, $C_{c l \text {-sea }}$ is the $\mathrm{Cl}^{-}$concentration of the seawater sample no. 29 (639.4 meq. $\left.\mathrm{L}^{-1}\right)$ and $C_{C l \text { fresh }}$ represents the $\mathrm{Cl}^{-}$concentration of the most fresh water sample in Sudr area (i.e., the rain water sample which has $\mathrm{Cl}$ concentration of 0.48 meq.L1, Said 2004).

The contribution of seawater (seawater fraction) varies from $2.4 \%$ (sample no. 36) to $62.1 \%$ (sample no. 1). The highest value of $f_{\text {seawater }}$ for sample No. (1) correspond to the highest measured values of $\mathrm{Cl}^{-}$and TDS of this water sample (14097 mg/l and $24383 \mathrm{mg} / \mathrm{l}$, respectively). Comparing the seawater fractions with the geographic locations of groundwater wells (see Fig. 4), it has been found that the contribution of seawater increases northwards. This finding has been confirmed from the high seawater fraction values observed due the north, while the lowest seawater fractions have been noted at wells of Wadi Wardan at the southern part of the study area (Table 5).

Table 5: Seawater fraction values of groundwater samples collected from Ras Sudr area.

\begin{tabular}{clllll}
\hline Sample no. & Location & $\boldsymbol{f}_{\text {seawater }}$ Sample no. & Location & $\boldsymbol{f}_{\text {seawater }}$ S \\
\hline $\mathbf{1}$ & North W. Lahata & 62.1 & 21 & Middle, N. Wadi Sudr & 4.3 \\
$\mathbf{2}$ & North, bet. Lah. \&Sudr & 21.7 & 22 & Middle, N. Wadi Sudr & 18.3 \\
$\mathbf{3}$ & North, bet. Lah. \&Sudr & 28.6 & 23 & Middle, N. Wadi Sudr & 9.5 \\
$\mathbf{4}$ & North, bet. Lah. \&Sudr & 33.7 & 24 & Middle, N. Wadi Sudr & 10.8 \\
$\mathbf{5}$ & North, bet. Lah. \&Sudr & 26.5 & 25 & Middle, N. Wadi Sudr & 9.5 \\
$\mathbf{6}$ & North, bet. Lah. \&Sudr & 14.7 & 26 & Middle, N. Wadi Sudr & 7.8 \\
$\mathbf{7}$ & North, bet. Lah. \&Sudr & 10.8 & 27 & Middle, Wadi Sudr & 8.2 \\
$\mathbf{8}$ & North, bet. Lah. \&Sudr & 16.7 & 28 & Middle, Wadi Sudr & 14.7 \\
$\mathbf{9}$ & North, bet. Lah. \&Sudr & 15.2 & 29, sea & Middle, Wadi Sudr & 100 \\
$\mathbf{1 0}$ & North, bet. Lah. \&Sudr & 6.5 & 30 & Middle, Wadi Sudr & 13.3 \\
$\mathbf{1 1}$ & North, bet. Lah. \&Sudr & 10.8 & 31 & Middle, Wadi Sudr & 16.8 \\
$\mathbf{1 2}$ & North, bet. Lah. \&Sudr & 5.1 & 32 & Middle, Wadi Sudr & 14.8 \\
$\mathbf{1 3}$ & North, bet. Lah. \&Sudr & 9.3 & 33 & Middle, Wadi Sudr & 17.0 \\
$\mathbf{1 4}$ & North, bet. Lah. \&Sudr & 11.7 & 34 & Middle, Wadi Sudr & 2.8 \\
$\mathbf{1 5}$ & North, bet. Lah. \&Sudr & 13.8 & 35 & South, W. Wardan & 4.5 \\
$\mathbf{1 6}$ & North, bet. Lah. \&Sudr & 25.6 & 36 & South, W. Wardan & 2.4 \\
$\mathbf{1 7}$ & North, bet. Lah. \&Sudr & 15.3 & 37 & South, W. Wardan & 2.9 \\
$\mathbf{1 8}$ & North, bet. Lah. \&Sudr & 14.7 & 38 & South, W. Wardan & 2.7 \\
$\mathbf{1 9}$ & Middle, N. Wadi Sudr & 3.8 & 39 & South, W. Wardan & 3.5 \\
$\mathbf{2 0}$ & Middle, N. Wadi Sudr & 7.8 & 40 & South, W. Wardan & 9.5 \\
\hline
\end{tabular}

\subsubsection{Seawater mixing index (SWMI):}

For quantitative estimation of the relative degree of seawater mixing in the water samples, the SWMI parameter has been used (Park et al., 2005, Monda1 \& Singh 2011). This parameter is based on the concentration of four major ionic constituents in seawater $\left(\mathrm{Na}^{+}, \mathrm{Mg}^{2+}, \mathrm{Cl}^{-}\right.$and $\left.\mathrm{SO}_{4}^{-2}\right)$ and its expression is as follows (equation 6):

$\mathrm{SWMI}=\mathrm{a} \times \frac{C(\mathrm{Na})}{T(\mathrm{Na})}+b x \frac{C(\mathrm{Mg})}{T(\mathrm{Mg})}+c x \frac{C(\mathrm{Cl})}{T(\mathrm{Cl})}+d x \frac{C(\mathrm{SO} 4)}{T\left(\mathrm{SO}^{2}\right)}$

Where, a, b, c and d are constants estimated according to the relative proportion of $\mathrm{Na}^{+}, \mathrm{Mg}^{2+}, \mathrm{Cl}^{-}$and $\mathrm{SO}_{4}^{-2}$ between average world groundwater and local Sudr groundwater (effluent), respectively, which are site specific. $\mathrm{C}(\mathrm{Na})$ is the calculated concentration of $\mathrm{Na}^{+}$in a groundwater sample (expressed in $\mathrm{mg} / \mathrm{l}$ ) and $\mathrm{T}(\mathrm{Na})$ represents the calculated regional threshold values of $\mathrm{Na}^{+}$ions (estimated from the interpretation of cumulative probability curves).

The SWMI is used to understand the occurrences of hydrogeochemical and mixing processes in shallow and deep aquifers. The probability distribution curves have great importance in dealing with 
the interpretation of geochemical data and the discrimination of processes affecting groundwater chemistry (Shaw 1961; Sinclair 1974; Sinclair 1976). In Figure 16 (A, B, C and D), inflection points indicate the equivalent regional threshold value; $\mathrm{T} i$ for $\mathrm{Na}^{+}, \mathrm{Mg}^{2+}, \mathrm{Cl}^{-}$and $\mathrm{SO}_{4}{ }^{2-}$ ions (Monda1 \& Singh 2011, Kumar 2014). Inflection points are estimated according to the distribution probability curves, where the inflections are mainly attributed to groundwater mixing with seawater. The estimated focal threshold ( $\left.\mathrm{T}_{i}\right)$ value for different ions is: $2100 \mathrm{mg} / \mathrm{l}$ for $\mathrm{Na}^{+}, 388.8 \mathrm{mg} / \mathrm{l}$ for $\mathrm{Mg}^{2+}, 4160$ $\mathrm{mg} / \mathrm{l}$ for $\mathrm{Cl}^{-}$and $1100 \mathrm{mg} / \mathrm{l}$ for $\mathrm{SO}_{4}{ }^{2-}$.
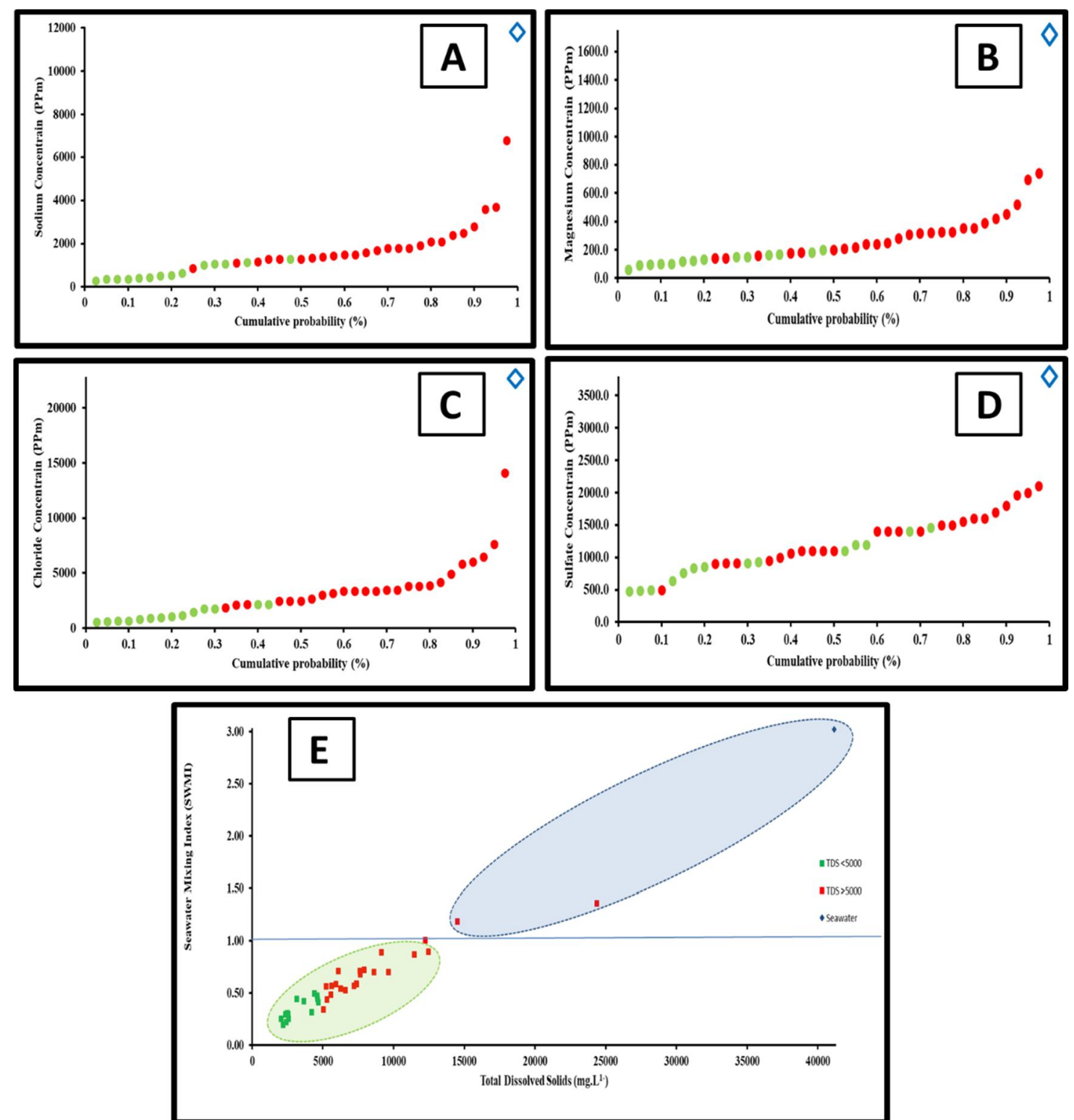

Fig. 16: Cumulative probability curves for the distribution of (A) $\mathrm{Na}^{+}$, (B) $\mathrm{Mg}^{2+}$, (C) $\mathrm{Cl}^{-}$, (D) $\mathrm{SO}_{4}{ }^{2-}$ in water samples (E) Cross-plot of seawater mixing index vs. total dissolved solids.

Based on the SWMI values, it was found that groundwater is classified into two Groups (Fig. 16 E). Group I $(0.2<$ SWMI $<0.89)$ less than unity and the groundwater has TDS ranges from 2202 to $12455 \mathrm{mg} / \mathrm{l}$ which indicate the subsurface meteoric groundwater recharge from the watershed. Group II $(1<$ SWMI < 3.02) has salinity range from 12252 to $41163 \mathrm{mg} / 1$ which is close to seawater. The elevated values of SWMI which are greater than one may indicate the mixing of groundwater with seawater, i.e., it is indication for seawater intrusion (Park et al., 2005). According to the SWMI values, the most affected water samples with seawater intrusion are samples Nos. 1, 4 and 16. This finding matches well with the high values of seawater fractions for these samples $(62.1,33.7$ and 25.6, respectively). 


\subsection{Multivariate statistical analysis}

The relationship between various physico-chemical components of groundwater were studied using correlation matrix and cluster analyses which are calculated by SPSS statistics software, (version 16.0). The main purpose of these multivariate statistical analyses in the current study is to identify the areas and water wells affected by seawater intrusion.

\subsubsection{Correlation matrix}

Correlation matrix is the relationship between two variables represented by a correlation coefficient (r) which shows how one variable predicts the other. It is often used as a simplified statistical tool to show the degree of dependency of one variable to the other (Kanade and Gaikwad 2011). A high correlation coefficient (nearly 1 or -1) means a good relationship between two variables, and a correlation coefficient around zero means no relationship. Positive values indicate a positive relationship, while negative values of $r$ indicate an inverse relationship. The results of correlation matrix calculations are shown in Table 6.

Table 6: Correlation matrix among major constituents of water samples collected from Ras Sudr area.

\begin{tabular}{llllllllll}
\hline Parameter & $\mathbf{p H}$ & $\mathbf{T D S}$ & $\mathbf{N a}^{+}$ & $\mathbf{K}^{+}$ & $\mathbf{C a}^{2+}$ & $\mathbf{M g}^{2+}$ & $\mathbf{H C O}^{-}$ & $\mathbf{S O}_{4}{ }^{2-}$ & $\mathbf{C l}^{-}$ \\
\hline $\mathbf{p H}$ & 1 & & & & & & & & \\
$\mathbf{T D S}$ & -0.204 & 1 & & & & & & & \\
$\mathbf{N a}^{+}$ & -0.166 & $.980^{* *}$ & 1 & & & & & & \\
$\mathbf{K}^{+}$ & -0.126 & $.667^{* *}$ & $.661^{* *}$ & 1 & & & & & \\
$\mathbf{C a}^{2+}$ & -0.185 & $.821^{* *}$ & $.719^{* *}$ & $.483^{* *}$ & 1 & & & & \\
$\mathbf{M g}^{2+}$ & -0.266 & $.893^{* *}$ & $.808^{* *}$ & $.595^{* *}$ & $.789^{* *}$ & 1 & & & \\
$\mathbf{H C O}_{3}{ }^{-}$ & -0.195 & $.991^{* *}$ & $.977^{* *}$ & $.659^{* *}$ & $.816^{* *}$ & $.884^{* *}$ & 1 & & \\
$\mathbf{S O}_{4}{ }^{2-}$ & -0.108 & -0.166 & -0.182 & -0.009 & -0.181 & -0.029 & -0.159 & 1 & \\
$\mathbf{C l}^{-}$ & -0.171 & $.381^{*}$ & 0.315 & 0.263 & 0.284 & $.422^{* *}$ & 0.258 & -0.079 & 1 \\
\hline
\end{tabular}

**. Correlation is significant at the 0.01 level.

*. Correlation is significant at the 0.05 level.

The above matrix shows that $\mathrm{pH}$ and $\mathrm{SO}_{4}{ }^{2-}$ have a negative correlation with the other constituents. On the other hand, TDS and major constituents showed a highly positive correlation between each other which implied that most of the groundwater samples were affected by saline waters enriched with most of these major ions. Finally, these correlations confirm that the groundwater acquires its quality from leaching and dissolution of salts by passage of groundwater into the aquifer matrix which consists of carbonates, marl, clay and calcareous sandstone.

\subsubsection{Cluster analysis}

Cluster analysis comprises a series of multivariate methods, which is used to group the variables based on their similar characteristics. The variables grouping into a cluster possess high homogeneity within cluster and high heterogeneity between clusters. The levels of the similarity at which observations are merged are used to construct a dendrogram (Lokhande et al., 2008). Agglomerative hierarchical clusters are formed sequentially, by starting with the most similar pair of objects and forming higher cluster step by step. To detect the similarity among groups, cluster analysis was applied on thirty-nine groundwater, one rain and one seawater sample. The investigation of the drawn dendrogram (Fig. 17) and based on hydrogeochemical data of the Quaternary aquifer, it was inferred that the collected groundwater samples have been divided into three clusters (CI, CII, CIII) as follow: 


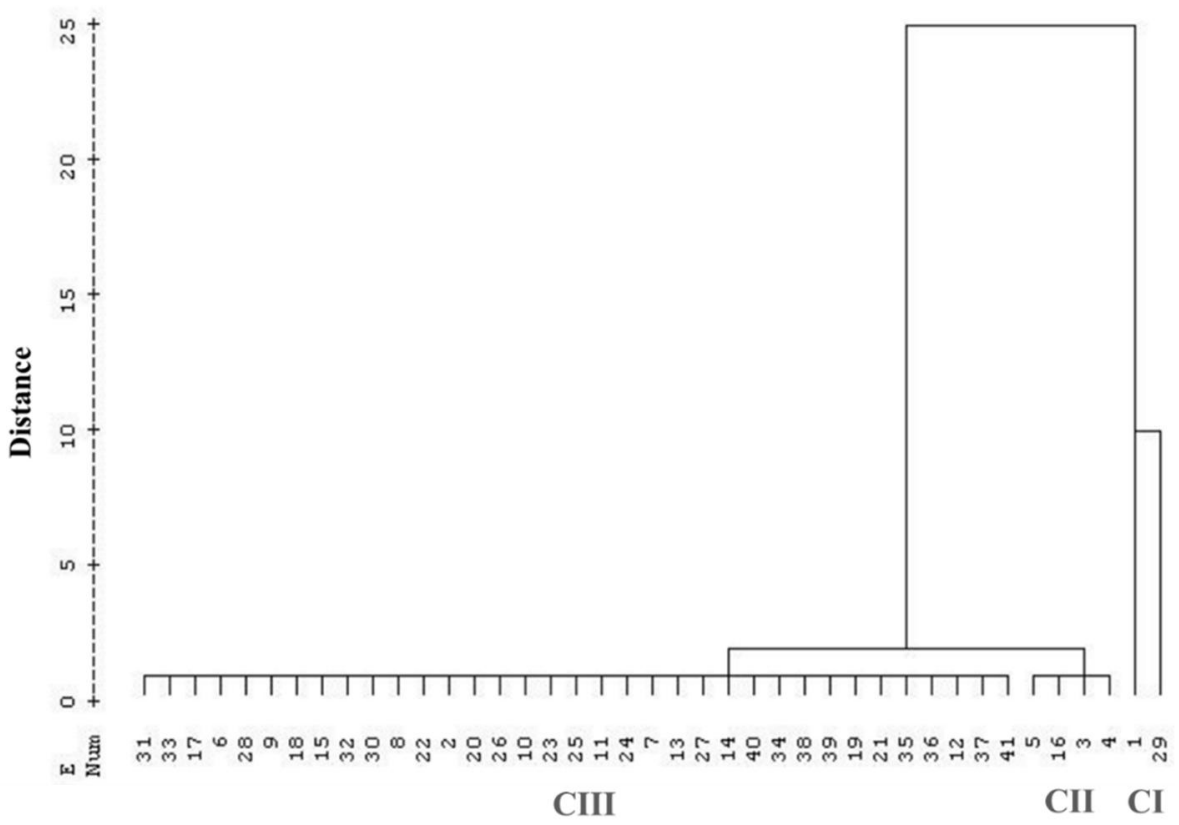

Fig. 17: Dendrogram of major ions of groundwater samples collected from the Quaternary aquifer, Ras Sudr area, Egypt.

The Cluster (CI) represents $3 \%$ of groundwater samples including sample No.1 and seawater (sample No. 29). This cluster indicates that well no.1 is the most affected well by the seawater intrusion where it has the highest salinity among the collected water samples (its TDS is $24383 \mathrm{mg} / \mathrm{l}$ ). Cluster (CII) represents $10 \%$ of samples including four samples $(3,4,5$ and 16$)$. These four samples are strongly affected by seawater intrusion with TDS range between 11470 and $14519 \mathrm{mg} / \mathrm{l}$. The Cluster (CIII) represents $87 \%$ of the water wells which are moderately to less affected by seawater intrusion with TDS range between 2037 and $9639 \mathrm{mg} / \mathrm{l}$. The moderately affected wells are located at the middle part of the study area (Wadi Sudr and its northern extension), while the less affected wells are located at the southern part of the study area (Wadi Wardan, see Fig. 4). The wells included in cluster II and III may be affected by processes other than seawater intrusion such as ion exchange and/or water-rock interactions. It is worthy to mention that the results of this cluster analysis match very well with seawater fraction and seawater mixing index results.

\section{Conclusions}

In coastal areas such as Ras Sudr area and even under the non-pumping conditions, the seawater would intrude the fresh groundwater of the coastal aquifer and forms a transition zone in the subsurface. Thus, the current research represents an attempt to evaluate the salinization processes (especially those due to the seawater intrusion) at the Quaternary aquifer in Ras Sudr area, southwest Sinai, Egypt. The investigation and analysis of these processes have been done using multivariate statistical analysis and groundwater chemistry data (such as bivariate diagrams and ionic ratios). The salinity of the Quaternary groundwater ranges from 2038 to $24383 \mathrm{mg} / \mathrm{l}$ indicating brackish to saline water category. The dominant water type is $\mathrm{Cl}-\mathrm{Na}$ which is represented by $87 \%$ of samples and it is the dominant water type at seawater as well. This may imply the effect of seawater intrusion process as shown at Piper diagram (where most samples have plotted at sub area 7 close to seawater point) and Chadha diagram (where most samples have plotted at seawater or $\mathrm{Na}-\mathrm{Cl}$ zone). The other water types present at the Quaternary groundwater are $\mathrm{SO}_{4}-\mathrm{Ca}$ and $\mathrm{SO}_{4}-\mathrm{Na}$ types. The current study prove that ionic ratios such as $\mathrm{Na}^{+} / \mathrm{Cl}^{-}$and $\mathrm{rCl}^{-} / \mathrm{HCO}_{3}{ }^{-}+\mathrm{CO}_{3}{ }^{2-}$ are important tools in the assessment of geochemical processes especially the seawater intrusion. The cluster analysis shows that well No. 1 is the most affected well by the seawater intrusion because it is included with seawater sample at the same cluster (CI), has the highest seawater fraction (62.1\%), and has seawater mixing index greater than 1 . The cluster (CII) includes samples $(3,4,5$ and 16) which are strongly affected by seawater because their seawater fraction ranges from 25.6 to $33.7 \%$. Well no. 1 (the closest well to Gulf of Suez shore) together with the wells represent cluster CII (which located south of Wadi Lahata due to 
the north of the study area) are severely intruded with seawater. Furthermore, wells of cluster CIII at the middle part of the study area (Wadi Sudr and its northern extension) are moderately affected by seawater intrusion as shown from the medium values of seawater fractions ( 7.8 to $17 \%$ ). Finally, wells of cluster CIII at southern part of the study area (Wadi Wardan wells except well no.40) is less affected by seawater intrusion as indicated from the low values of seawater fractions (2.4 to $4.5 \%)$. In general, the inland wells at Wadi Wardan due to the south are less affected by seawater intrusion than the wells more close to the Gulf of Suez shore at Wadi Lahata and Wadi Sudr as well as the area between them due to the north. The other processes affecting groundwater quality of the Quaternary aquifer are shown to be ion exchange and water-rock interactions (especially carbonate dissolution).

\section{Acknowledgments}

The third author (Y.A. Maher) has been financially supported from the Academy of Scientific Research and Technology, Egypt (via a Master scholarship in 2018) and partially through grant number 4369.

\section{References}

Abdalla, F., 2016. Ionic ratios as tracers to assess seawater intrusion and to identify salinity sources in Jazan coastal aquifer, Saudi Arabia. Arab J. of Geosci, 9(40). https://doi.org/10.1007/s12517015-2065-3

Abdel Gawad, M., 1970. The Gulf of Suez, a brief review of stratigraphy and structure" Phil.Trans. Roy. Soc. Lond., A267:41-48.

Abdel Latief, T.A., and A.M. Al Temamy, 2008. Study of the impact of groundwater discharge on the brackish-saline interface using two-dimensional resistivity imaging in the Delta of Wadi Sudr, Western Sinai, Egypt. Journal Desert Research, 58 (1): 1-17.

Abdel-Lattif, A., and Y. Sherief, 2010. Morphometric analysis and flash floods of Wadi Sudr and Wadi Wardan, Gulf of Suez, Egypt: using digital elevation model. Arab J. Geosci, 5:181-195. DOI 10.1007/s12517-010-0156-8

Abdel-Hafez, A.A., 2001. Chemical evaluation and possible treatment of seawater intrusion in the groundwater in some coastal areas. South Sinai, M. Sc. Thesis, Fac of Science, Al Azhar Univ (girls), 223.

Abo Shalaa, N.E., 2016. Hydrologic assessment of Wadi Sudr and vicinities, South Sinai, Egypt. PhD thesis, Fac. Sci., Ain Shams Univ.

Apello, J., and D. Postma, 2005. Geochemistry, groundwater and pollution, 2nd edn. Balkema, CRC Press, Roterdam.

APHA: American Public Health Association, 1995. Standard methods for the examination of water and waste water, 17th edn. Washington DC, USA.

ASTM: American Society for Testing and Materials, 2002. Water and environmental technology. Annual book of ASTM standards, USA, Sec. 11, 11.01, and 11.02, West Conshohocken.

Bear, J., A. Cheng, S. Sorek, and D. Ouazar, 1999. Seawater Intrusion in Coastal Aquifers concepts. Methods, and Practices. Kluwer Academic Publishers, Dordrecht, the Netherlands.

Chadha, D., 1999. A proposed new diagram for geochemical classification of natural waters and interpretation of chemical data. Hydrogeol J., 7(5):431-439.

Chebotarev, I., 1955. Metamorphism of natural waters in the crust of weathering-1. Geochimica et Cosmochimica Acta, 8(1-2):22-48.

Conoco, 1987. Geological map of Egypt, Scale 1:500000", 6 Sheets, with cooperation of Egyptian General Petroleum Corporation, Klitzsch E., List F.K. and Pohlmann G.(Editors), Berlin, Germany and Cairo, Egypt.

El-Fiky, A.A., 2010. Hydrogeochemical Characteristics and Evolution of Groundwater at the Ras Sudr-Abu Zenima Area, Southwest Sinai, Egypt. JKAU: Earth Sci., 21(1): 79-109 (2010 A.D. / 1431 A.H.) DOI: 10.4197 / Ear. 21-1.4

El Moujabber, M., B. BouSamra, T. Darwish, and T. Atallah, 2006. Comparison of different indicators for groundwater contamination by seawater intrusion on the Lebanese coast. Water Resour Mang., 20:161-180. 
El Sayed, E., Y.L. Ismail, M.A. Gomaa, 1999. Hydrogeological investigation in the coastal area of the delta of Wadi Sudr, Gulf of Suez, South Sinai, Egypt." Bull. Fac. of Science, Assuit Univ., $143-160$

Gad, M.A., 1996. Hydrology of wadis in Sinai. M.Sc. Thesis, Faculty of Science, Ain Shams University, Egypt.

Gibbs, R.J., 1970. Mechanisms controlling world water chemistry. Science, 170(3962):1088-1090.

Hammad, F.A., 1980. Geomorphological and Hydrogeological aspects of Sinai Peninsula. $5^{\text {th }}$ African conference, A.R.E., Ann Geol. Surv. Egypt, 10:807-817.

Hasanein, A.H.M., 1989. Geology of water resources in Wadi Sudr-Wadi Gharandal area, Gulf of Suez region, Sinai Peninsula, Egypt. M. Sc Thesis Fac. of Science, Ain Shams Univ., 145.

Hem, J.D., 1989. Study and interpretation of the chemical characteristics of natural water. U. S. Geol. Sur. Water Supply Paper 2254, Third Edition.

Howard, K.W.F., and J.W. Lloyd, 1983, Major ion characterization of coastal saline ground waters: Groundwater, 21(4): 429-437.

Hussien, R.A., 2015. Groundwater Quality Index Studies for Seawater Intrusion in Coastal Aquifer Ras Sudr, Egypt Using Geographic Information System. Middle East J. Appl. Sci., 5(1):209222.

Ibrahim, S.M., 2012. Monitoring of seawater encroachment in the delta of Wadi Sudr, South Sinai, Egypt. Assiut University Journal of Geology, 41(1):32-60.

Jacobson, R.L., and D. Langmuir, 1970. The chemical history of some spring waters in carbonate rocks a. Groundwater, 8(3):5-9.

Jones, B.F., A. Vengosh, E. Rosenthal, and Y. Yechieli, 1999, Geochemical Investigations, Chapter 3 in Seawater intrusion in coastal aquifers-Concepts, methods, and practices book: Kluwer Academic Publishers- Dordrecht I Boston I London, 625.

Kanade S, and V. Gaikwad, 2011. A multivariate statistical analysis of bore well chemistry data: Nashik and Niphad Taluka of Maharashtra, India. Universal Journal of Environmental Research and Technology, 1(2):193-202.

Khaska, M., C. La Salle, J. Lancelot, A. Mohamad, P. Verdoux, A. Noret, and R. Simler, 2013. Origin of groundwater salinity (current seawater vs. saline deep water) in a coastal karst aquifer based on $\mathrm{Sr}$ and $\mathrm{Cl}$ isotopes, Case study of the La Clape massif (southern France). Appl. geochemistry, 37:212-227.

Kumar, P.S., 2014. Evolution of groundwater chemistry in and around Vaniyambadi industrial area: differentiating the natural and anthropogenic sources of contamination. Chemie der ErdeGeochemistry, 74(4):641-651.

Langelier, W.F., 1936. The analytical control of anticorrosion water treatment, Journal of American Works Association, 28:1500-1521

Lokhande, P.B., V.V. Patil, and H.A. Mujawar, 2008. Multivariate statistical analysis of ground water in the vicinity of Mahad industrial area of Konkan Region, India. International Journal of Appl. Environmental Sciences, 3(2):149-164.

Maher, Y.A., 2020. Usage of polymeric materials for the removal of seawater hardness in desalination plants. M.Sc. thesis, Fac. Sci., Ain Shams Univ.

Meisler, H., and A.E. Becher, 1967. Hydrogeologic significance of calcium-magnesium ratios in groundwater from carbonate rocks in the Lancaster Quadrangle, southeastern Pennsylvania. US Geological Survey professional paper, C232-C235.

Misak, R.F., S.M. Atwa, M.K. Sallouma, and A.H. Hassanein, 1995. Geology and water quality of the groundwater supplies in Sudr-Gharandal area, Gulf of Suez, Egypt. Bull. Fac. Sci., Assiut Univ., 24 (2-F):1-21.

Mondal, N., and V. Singh, 2011. Hydrochemical analysis of salinization for a tannery belt in Southern India. Journal of Hydrology, 405(3-4):235-247.

Morad, N., 2000. Rainfall-Runoff Relationship in Mountainous Areas; Case study Wadi Sudr, M. Sc. thesis, Faculty of Engineering, Ain Shams University, Cairo, Egypt.

Park, S.C., S.T. Yun, G.T. Chae, I.S. Yoo, K.S. Shin, C.H. Heo, and S.K. Lee, 2005. Regional hydrochemical study on salinization of coastal aquifers, western coastal area of South Korea. Journal of Hydrology, 313(3-4):182-19. 
Piper, A.M.,1953. A graphic procedure in the geochemical interpretation of water analyses. American Geophysical Union Transactions, 25(105):914-923.

Plummer, L.N., E.C. Prestemon, and D.L. Parkhurst, 1994. An interactive code (NETPATH) for modeling net geochemical reactions along a flow path Version 2.0. Water-Resources Investigations Report 94-4169. Reston, Virginia: U.S. Geological Survey.

Pomper, A.B., 1981. Hydrochemical observations in the subsoil of the western part of the Netherlands ; Proceedings, Seventh saltwater intrusion meeting, Uppsala, Sweden, 101-111.

Prinos, S.T., M.A. Wacker, K.J. Cunningham, and D.V. Fitterman, 2014. Origins and delineation of saltwater intrusion in the Biscayne aquifer and changes in the distribution of saltwater in Miami-Dade County, Florida. In: U.S. Geological Survey Scientific Investigations Report, 2014-5025.

Richter, B.C., and C.W. Kreitler, 1993, Geochemical techniques for identifying sources of groundwater salinization: Boca Raton, FL, CRC Press, 258.

Said, M., 2004. Geochemistry of groundwater in coastal areas, South Sinai, Egypt, Ph.D Thesis, Fac Sci, Ain Shams Univ, Egypt.

Said, R., 1990. The geology of Egypt, Balkema, Rotterdam, Rookield, 743.

Schoeller, H., 1965. Hydrodynamique lans lekarts (ecoulemented emmagusinement). Actes Colloques Doubronik, I, AIHS et UNESCO,3-20.

Shaw, D., 1961. Element distribution laws in geochemistry. Geochimica et Cosmochimica Acta, 23(12):116-134.

Simpson, T.R., 1946. Salinas's basin investigation Sacramento: Bull. 52, Calif. Div. Water resources, 230.

Sinclair, A., 1974. Selection of threshold values in geochemical data using probability graphs. Journal of Geochemical Exploration, 3(2): 129-149.

Sinclair, A., 1976. Applications of probability graphs in mineral exploration: Association of Exploration Geochemists, Special, .4: 96. Google Scholar. 